\title{
Measuring the Performance of River Basins: Application of Total Factor Productivity Approach to Andhra Pradesh, India
}

\author{
K. Palanisami ${ }^{1}$ and C. R. Ranganathan ${ }^{2}$ \\ ${ }^{1}$ International Water Management Institute (IWMI), ICRISAT Campus, Patancheru 502324, Hyderabad, India \\ ${ }^{2}$ Department of Physical Sciences and Information Technology, Tamil Nadu Agricultural University, Coimbatore 641003, India
}

Correspondence should be addressed to K. Palanisami, k.palanisami@cgiar.org

Received 31 March 2012; Accepted 29 May 2012

Academic Editor: Thomas D. Crocker

Copyright ( $) 2012$ K. Palanisami and C. R. Ranganathan. This is an open access article distributed under the Creative Commons Attribution License, which permits unrestricted use, distribution, and reproduction in any medium, provided the original work is properly cited.

\begin{abstract}
Total Factor Productivity (TFP) measures the growth in output which is not accounted for by inputs. Data Envelopment Analysis which forms the basis for the computation of Malmquist TFP index is used in this paper to study the performance of different river basins in Andhra Pradesh state, India. The results indicated that average technical efficiency of all the basins is only $66 \%$. In all the basins there was a decline in growth of agricultural output during the first two decades, viz., 1979-1980 to 1988-1989 and it had picked in the last decade (1999-2000). All the river basins have TFP change greater than 1 indicating progress in agricultural productivity. Out of the 40 river basins, 14 river basins have technical efficiency change less than 1 indicating decline in TFP growth whereas all the basins have technical changes greater than 1 implying that there is shift in production frontier over years. In general, within the TFP, technical change contributed more than technical efficiency change. Looking at the future options for increasing the agricultural output in the river basins, it is important to focus on improving the TFP growth compared to increasing the quantities of physical inputs.
\end{abstract}

\section{Introduction}

In India, the share of agriculture and allied sectors in total GSDP is declining over years. For example in the case of Andhra Pradesh state which is one of the leading states in India, the share of the GSDP during 2008-09 and 200910 at constant (1999-2000) prices, is 26.34 and $25.34 \%$, respectively, which was $32 \%$ during 1990s. Hence there is a growing concern on stabilizing the share of agriculture sector to the GSDP. River basins play a major role in contributing to the agricultural growth as they encompass all aspects of agriculture, namely, rainfed, irrigated, surface water and groundwater, and so forth. Hence studying the agricultural growth of the state using basin-wise data will be more relevant to formulate suitable policies for improving the performance in agricultural sector. Usually performances of the river basins are studied using various indicators such as area irrigated, area cultivated, water use efficiency, income per unit of water, and so forth, where mostly the inputs use efficiency is focused. However, it is difficult to relate the performance owing to variety of other issues such as irrigated versus rain-fed area, agriculture versus other benefits (such as livestock), management, technologies, and so forth. Hence a holistic approach to measure the growth in productivity taking into account all physical and management inputs and outputs is necessary. Further the methodology should be able to identify the sources of growth which will be important for policy makers. Total factor productivity (TFP) approach is obviously a suitable methodology to apply for such multiinput and multioutput technologies.

TFP measures the growth in output which is not accounted for by inputs. It is usually calculated as a ratio of output to input. In other words, productivity increases when growth in output surpasses growth in input. No doubt increase in inputs, if used efficiently, will produce productivity growth. But inputs are subject to diminishing marginal rates of return. Hence ideally, economists and government aim for productivity growth without an increase in inputs. However, measurement of total input and total output in a multioutput, multiinput framework is both conceptually and 
empirically difficult unless measurement methodologies are used effectively. In these situations, Malmquist index (MI) provides opportunities to measure growth in any production sector and in particular in agriculture.

One important area of interest for researchers and policy makers is to measure not only the levels and trends in agricultural productivity but also to identify the sources for its growth. Traditionally index number approach (e.g., Tornqvist-Theil TFP index) has been applied to estimate TFP. This approach requires historical data on quantities of all outputs, their prices, and quantities of all inputs and their costs. Further the method does not lend support for decomposition of the index into different attributable sources. But historical data on prices are not accurately available and even if they are available their accuracies are questionable because of spatial variations and other reasons. Hence new techniques which do not require price and cost data have developed. These approaches can be classified as parametric and nonparametric. The MI is a nonparametric approach based on distance functions. It is a popular tool to measure and analyze productivity growth. Most important for the study is its ability to decompose productivity growth into two mutually exclusive and exhaustive components: changes in technical efficiency over time (catching up) and shifts in technology over time (technical change). A major advantage cited in support of this methodology is that these methods do not require any price data. The objective of this paper is to study the performance of the river basins of Andhra Pradesh using total factor productivity analysis and to suggest the ways and means of improving the performance of the river basins in the state.

\section{Review of Past Studies Using Malmquist TFP Index}

Methods to estimate TFP can be classified in four major groups:

(i) least-squares econometric production models,

(ii) growth accounting TFP indices,

(iii) stochastic frontiers [1],

(iv) data envelopment analysis (DEA).

The first two methods are normally used with times series data and assume that all production units are technically efficient. In the third method, which is a parametric method, a stochastic frontier is obtained for all the firms for a given year such that all the firms either lie on or below the stochastic frontier. Those firms which lie below the frontier are said to be inefficient. The frontier may shift up or down as time changes and the output growth is decomposed into technical efficiency change, technological change, and input growth [2]. MI is a nonparametric method based on data envelopment analysis. Both parametric and nonparametric methods can be applied to a cross-section of firms, farms, regions, or basins to compare their relative productivity. MI has become a standard tool to measure productivity after Färe et al. [3] showed that the index can be estimated using a nonparametric approach.
There are a number of papers on the application of Malmquist index to study productivity growth in agriculture. Coelli and Rao $[4,5]$ applied Malmquist index approach to study the total factor productivity growth in agriculture in 93 countries using panel data for the years 1980-2000. The results show an annual growth in total factor productivity growth of 2.1 percent, with efficiency change contributing 0.9 percent per year and technical change providing the other 1.2 percent. The study showed that China has the maximum annual TFP growth of 6 percent per year.

Yuk-shing [6] studied TFP growth in agriculture in 64 counties in Jiangsu province of China during 1980 to 1995. The study indicated that the total factor productivity growth in agriculture was as high as $7.8 \%$ per annum during 1991-95. The decomposition result showed that there was rapid technical progress, along with a substantial decline in technical efficiency.

Rungsuriyawiboon and Lissista [7] applied Malmquist productivity index approach to productivity growth in European agricultural sector. They used a panel data on 44 countries over the time period of 1992-2002. The study showed that the TFP growth during the period was 3.03 percent of which 0.75 percent was due to technical efficiency change and the balance of 2.28 percent was from technical change.

Umetsu et al. [8] studied the efficiency and technical change in Philippine rice sector for the period 1971-1990 and found that annual Malmquist productivity growth was found to be only slightly positive. Productivity growth was negative during the early 1970s, and was followed by a period of positive growth, and negative growth in the late 1980s. The period of positive growth coincided with the introduction of new rice varieties while the declines may have been caused by intensification of rice production in lowland systems.

Linh [9] applied this methodology to study agricultural productivity in 60 provinces of Vietnam. The study showed that most of the growth in Vietnamese agriculture during the period 1985 to 1990 was due to TFP growth. During the later periods from 1990 to 2000, the TFP growth fell and TFP growth shared $38 \%$ of agricultural growth.

More recently Palanisami et al. [10] applied Malmquist index to study productivity growth in the 17 river basins of Tamil Nadu. They used the panel data for 30 years and studied the productivity growth pre- and-post liberalization periods. All river basins had shown negative growth rate in pre-liberalization period except P.A.P basin. In postliberalization period basins, namely Chennai, Palar, Varahanadhi, Ponnaiyaar, Paravanar, Vaippar, Thambaraparani, and Nambiar river basins have shown positive growth rate. All other river basins showed negative growth rate in post-liberalization period. The positive growth rate was mainly due to efficiency of inputs used for agriculture and livestock.

\section{Methodology}

The most popular form for estimating TFP growth in the past was the Tornqvist index. The Tornqvist index calculates TFP 
growth based on information concerning prices, and uses cost/revenue shares as weights to aggregate inputs/outputs. However, when calculating the Törnqvist index, observed output is assumed to be equivalent to frontier output. Consequently, decomposition of the TFP growth into the movements towards (efficiency improvement) and shifts in the production frontier (technical change) is not possible.

The Malmquist productivity index has gained popularity since Färe et al. [3] applied the linear-programming approach to calculate the distance functions that make up the index. There are several advantages of Malmquist index over the conventional approach to the measurement of productivity within nonfrontier framework such as Tornqvist or Fisher index.

First of all, since the data envelopment type of analysis can be directly applied to calculate the index, the Malmquist index has the advantage of computational ease. Secondly, the Malmquist productivity index permits TFP growth to be decomposed into technological change and technical efficiency change. Further, it requires neither price information nor behavioral assumption such as cost minimization, revenue maximization, or profit maximization. So, it is less data-demanding than the Törnqvist index. This makes it preferable when prices are distorted or missing and in those cases in which producers' objectives are different, unknown or simply unfeasible. The next section briefly describes the data envelopment analysis which forms the basis for the computation of Malmquist TFP index.

3.1. Data Envelopment Analysis (DEA). DEA is a nonparametric mathematical programming approach to frontier estimation [1]. DEA uses data on the input and output quantities to construct a piece wise linear surface over the data points. This frontier surface is constructed from the solution of a sequence of linear programming problems.

DEA can be either input orientated or output-orientated. In the input orientated case, the DEA method defines the frontier by seeking the maximum possible proportional reduction in input usage (called input-oriented technical efficiency), with output levels held constant for each basin; while in the output-orientated case, it seeks the maximum proportional increase in output production (called outputoriented technical efficiency), with input levels held fixed. The two measures provide the same level of technical efficiency scores when a constant returns to scale (CRS) technology applies, but are unequal when variable returns to scale (VRS) is assumed.

In this study, we select an output orientation with assumption of constant returns-to-scale because we believe it would be fair to assume that in agriculture, one usually attempts to maximize output from a given set of inputs, rather than the converse. The DEA model with output orientation can be specified as follows:

If one has data for $N$ basins in a particular time period, the linear programming (LP) problem that is solved for the ith basin in an output-orientated DEA model is as follows:

$$
\begin{array}{ll}
\max _{\phi, \lambda} & \phi, \\
\text { st } & -\phi y_{i}+Y \lambda \geq 0, \\
& x_{i}-X \lambda \geq 0, \\
& \lambda \geq 0,
\end{array}
$$

where $y_{t}$ is an $M \times 1$ vector of output quantities for the $i$ th basin; $x_{i}$ is a $K \times 1$ vector of input quantities for the $i$ th basin; $Y$ is an $N \times M$ matrix of output quantities for all $N$ basins; $X$ is an $N \times K$ matrix of input quantities for all $N$ basins; $\lambda$ is an $N \times 1$ vector of weights $\phi$ is a scalar.

It must be noted that the parameter $\phi$ will take a value greater than or equal to one and that $\phi-1$ is the proportional increase in outputs that could be achieved by the $i$ th basin with input quantities held constant. Note also that $1 / \phi$ defines a technical efficiency (TE) score that varies between 0 and 1 and it denotes the output oriented technical efficiency score. A technical efficiency score of 1 means 100\% efficient.

The above LP is solved $N$ times; once for each basin in the sample. Each LP produces a $\phi$ and a $\lambda$ vector. The $\phi$ vector provides information on the technical efficiency score for the $i$ th basin the $\lambda$ vector provides information on the peers of the (inefficient) $i$ th basin. The peers of the $i$ th basin are those efficient basins that define the facet of the frontier against which the (inefficient) $i$ th basin is projected.

3.2. Distance Functions and the Malmquist TFP Index. Distances are good tools to study multiinput and multioutput production technologies. They do not require behavioural assumptions such as cost minimization or profit maximization. Since Malmquist index is based on distance functions, a brief discussion on these functions is necessary. For this, following [3], we first define a production technology. It is the output set $P(x)$ which represents the set of all output vectors $y$ which can be produced using the input vector $x$. That is,

$$
P(x)=\{y: x \text { can produce } y\} .
$$

That is, for each time period $t=1,2, \ldots T$, the production technology describes the possibilities for the transformation of inputs $x_{t}$ into outputs $y_{t}$. This is the set of output vectors that can be produced with input vector $x$. For the technology in period $t$ and with $y_{t} \in R_{m}^{+}$outputs and $x_{t} \in R_{n}^{+}$inputs, the frontier of the output possibilities for a given input vector is defined as the output vector that cannot be increased by a uniform factor without leaving the set. The output distance function is defined on the output set $P(x)$ as

$$
d_{o}(x, y)=\min \left\{\delta:\left(\frac{y}{\delta}\right) \in P(x)\right\} .
$$

The distance function $d_{0}(x, y)$ will take a value which is less than or equal to 1 if the output vector $y$ is an element of the feasible production set $P(x)$. Furthermore, it will take a value of 1 if $y$ is located on the outer boundary of the feasible 
production set, and it will take a value greater than 1 if $y$ is located outside the feasible production set. In our study we use DEA-like methods to calculate our distance measures.

It can be seen from the definition that the output distance function is the reciprocal of Farrell's [11] outputoriented measure of efficiency. The distance function for the time period $t$ is denoted by $d_{0}^{t}\left(y_{t}, x_{t}\right)$. A firm is considered technically efficient if the distance function equals one.

In Malmquist index we use mixed period (outputoriented) distance functions to study the productivity change over time. These are defined by

$$
\begin{aligned}
& d_{0}^{t}\left(x_{t+1}, y_{t+1}\right)=\min \left\{\theta: \frac{y_{t+1}}{\theta} \in P^{t}\right\}, \\
& d_{0}^{t+1}\left(x_{t}, y_{t}\right)=\min \left\{\theta: \frac{y_{t}}{\theta} \in P^{t+1}\right\} .
\end{aligned}
$$

The first distance function defines the maximum possible expansion of output of period $t+1, y_{t+1} / d_{0}^{t}\left(x_{t+1}, y_{t+1}\right)$, that belongs to production technology of period $t$ and obtained by using inputs of the period $t+1$. The second distance function defines the maximum possible expansion of output of period $t, y_{t} / d_{0}^{t+1}\left(x_{t}, y_{t}\right)$, that belongs to production technology of period $t+1$ and obtained by using inputs of the period $t$. Productivity changes can be measured relative to period $t$ or period $t+1$. These two measures are defined by

$$
\begin{aligned}
m_{0}^{t} & =\frac{d_{0}^{t}\left(x_{t+1}, y_{t+1}\right)}{d_{0}^{t}\left(x_{t}, y_{t}\right)}, \\
m_{0}^{t+1} & =\frac{d_{0}^{t+1}\left(x_{t+1}, y_{t+1}\right)}{d_{0}^{t+1}\left(x_{t}, y_{t}\right)} .
\end{aligned}
$$

When there is one input and one output, these two measures are equal but in the multiinput, multioutput case they may differ.

The Malmquist index measures the TFP change between two data points (e.g. those of a basin in two different time periods) by calculating the ratio of the distance of each data point relative to a common technological frontier. Following Färe et al. [3], the Malmquist output-oriented index between period $t$ and $t+1$ is given by

$$
m_{0}\left(x_{t}, y_{t} x_{t+1}, y_{t+1}\right)=\left[\frac{d_{0}^{t}\left(x_{t+1}, y_{t+1}\right)}{d_{0}^{t}\left(x_{t}, y_{t}\right)} \times \frac{d_{0}^{t+1}\left(x_{t+1}, y_{t+1}\right)}{d_{0}^{t+1}\left(x_{t}, y_{t}\right)}\right]^{1 / 2}
$$

which is the geometric mean of two Malmquist indices: one using the technology frontier in $t$ as the reference, and a second index that uses frontier in $t+1$ as the reference. The Malmquist output-oriented index between periods $s$ (base period) and $t$ can be similarly defined:

$$
m_{0}\left(x_{s}, y_{s}, x_{t}, y_{t}\right)=\left[\frac{d_{0}^{s}\left(x_{t}, y_{t}\right)}{d_{0}^{s}\left(x_{s}, y_{s}\right)} \times \frac{d_{0}^{t}\left(x_{t}, y_{t}\right)}{d_{0}^{t}\left(x_{s}, y_{s}\right)}\right]^{1 / 2}
$$

A value of $m_{0}$ greater than 1 will indicate positive TFP growth from period $s$ to period $t$ while a value less than 1 indicates a TFP decline. It can be noted from the above

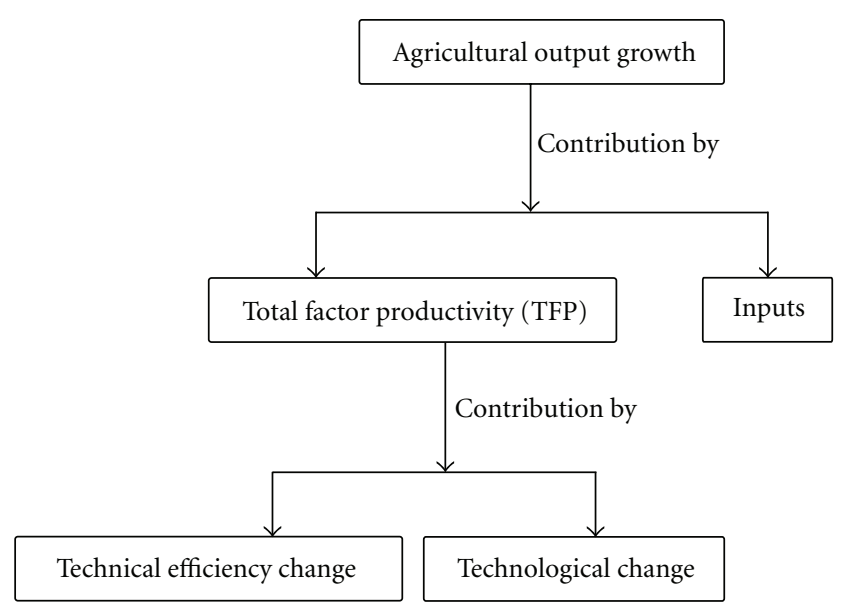

FIGURE 1: Flow chart showing Agricultural output growth contribution by TFP and inputs.

equation that TFP change is in fact the geometric mean of two TFP indices. The first is evaluated with respect to period $t$ technology and the second with respect to period $s$ technology.

Färe et al. [3] showed that the Malmquist index could be decomposed into an efficiency change component and a technical change component (Figure 1), and that these results applied to the different period-based Malmquist indices. This can be seen by rewriting the above equation in an equivalent form as

$$
m_{0}\left(x_{s}, y_{s}, x_{t}, y_{t}\right)=\frac{d_{0}^{t}\left(x_{t}, y_{t}\right)}{d_{0}^{s}\left(x_{s}, y_{s}\right)}\left[\frac{d_{0}^{s}\left(x_{t}, y_{t}\right)}{d_{0}^{t}\left(x_{t}, y_{t}\right)} \times \frac{d_{0}^{s}\left(x_{s}, y_{s}\right)}{d_{0}^{t}\left(x_{s}, y_{s}\right)}\right]^{1 / 2} .
$$

The ratio outside the square brackets measures the change in the output-oriented measure of Farrell technical efficiency between periods $s$ and $t$. It is called efficiency change. That is, the efficiency change is equivalent to the ratio of the technical efficiency in period $t$ to the technical efficiency in period $s$. The remaining part of the index in the above equation is a measure of technical change. It is the geometric mean of the shift in technology between the two periods, evaluated at $x_{t}$ and $x_{s}$. A value of the efficiency change component of the Malmquist index greater than one means that the production unit is closer to the frontier in period $t$ than it was in period $s$. That is the production unit is catching up to the frontier. A value less than one indicates efficiency regress. The same range of values is valid for the technical change component of total productivity growth, meaning technical progress when the value is greater than one and technical regress when the index is less than one.

The distance functions are estimated by using linear programming techniques. The methodology used in $[4,5]$ is followed in our study. It is given briefly below.

Given the panel data, we can calculate the required distance measures for the Malmquist TFP index using DEAlike linear programs. For the $i$ th basin, we must calculate four distance functions to measure the TFP change between 
two periods $s$ and $t$. This requires solving of four linear programming (LP) problems. Assuming constant returnsto-scale (CRS) technology, the required LPs are as follows:

LP1:

$$
\begin{array}{ll}
{\left[d_{0}^{t}\left(y_{t}, x_{t}\right)\right]^{-1}} & =\max _{\phi, \lambda} \phi \\
\text { st } & -\phi y_{i t}+Y_{t} \lambda \geq 0, \\
& x_{i t}-X_{t} \lambda \geq 0, \\
& \lambda \geq 0
\end{array}
$$

LP2:

$$
\begin{array}{ll}
{\left[d_{0}^{s}\left(y_{s}, x_{s}\right)\right]^{-1}} & =\max _{\phi, \lambda} \phi \\
\text { st } \quad & -\phi y_{i s}+Y_{s} \lambda \geq 0, \\
& x_{i s}-X_{s} \lambda \geq 0, \\
& \lambda \geq 0,
\end{array}
$$

LP3:

$$
\begin{array}{ll}
{\left[d_{0}^{t}\left(y_{s t}, x_{s}\right)\right]^{-1}} & =\max _{\phi, \lambda} \phi, \\
\text { st } \quad & \phi y_{i s}+Y_{t} \lambda \geq 0, \\
& x_{i s}-X_{t} \lambda \geq 0, \\
& \lambda \geq 0,
\end{array}
$$

LP4:

$$
\begin{array}{ll}
{\left[d_{0}^{s}\left(y_{t}, x_{t}\right)\right]^{-1}} & =\max _{\phi, \lambda} \phi, \\
\text { st } \quad & \phi y_{i t}+Y_{s} \lambda \geq 0, \\
& x_{i t}-X_{s} \lambda \geq 0, \\
& \lambda \geq 0 .
\end{array}
$$

It can be noted that in LPs 3 and 4, where production points are compared to technologies from different time periods, the parameter $\phi$ need not be greater than or equal to one, as it must be when calculating standard output-orientated technical efficiencies. The data point could lie above the production frontier. This will most likely occur in LP 4 where a production point from period $t$ is compared to technology in an earlier period, $s$. If technical progress has occurred, then a value of $\phi<1$ is possible. It could also possibly occur in LP 3 if technical regress has occurred, but this is less likely.

A good source for further details on the methodology is Coelli et al. [1]. There are many software packages available to compute the TFP index. In the present study DEAP (version 2.1) software package developed by Tim Coelli [12] was used.

\section{Profile of the Study Area}

Andhra Pradesh with a geographic area of $2,75,069 \mathrm{~km}^{2}$ is the fourth largest state of India by area with a population of about 76 millions and it ranks fifth position in terms of population. It has 23 districts and it is predominantly an agriculture state. It is the third largest rice-producing state with a share of $39.84 \%$ of geographical area as net sown area. Its cropping intensity was 1.27 during 2008-09. It has 62.1 lakh ha $(22.6 \%$ of geographical area) as forest cover and 26.52 lakh ha are not put under agricultural use. The net irrigated area is about 48 lakh ha with a respective share of $48.2 \%$ and $34.6 \%$ for wells and canals as sources of irrigation. The state produced about 204 lakh tones of food grains and 20.6 lakh tones of oilseeds during 2008-09 [13].

Andhra Pradesh has a normal seasonal rainfall of about $940 \mathrm{~mm}$ of which $624 \mathrm{~mm}$ are obtained from South West Monsoon (June to September). However, all the data related to agricultural performance of the State are available only district wise which are difficult to relate with the river basin boundaries. Hence it is important to transform the district level data to basin level for making basin level comparisons. This will also help to work out the performance of both irrigation and agriculture sectors at basin level.

The 40 river basins of Andhra Pradesh state constitute the study area. Out of these, Krishna, Godavari, and Pennar are the three largest basins with respective geographical areas being 7426975 ha, 7313950 ha, and 5036365 ha and these three basins together constitute $55 \%$ of the geographical area of Andhra Pradesh. The total area under all the remaining 37 basins constitute 7696046 ha. Among these 37 basins Gundlakamma basin which falls in Guntur and Prakasam districts is the largest with an area of 813222 ha. Major share of this basin belongs to Prakasam district with an area of 646428 ha. The next largest basin is Romperu which also falls in the same two districts. It has an area of 599158 ha. The sixth largest basin is Nagavali. Its area is 526446 ha with 337268 ha belonging to Vijayanagarm district and 189178 ha belonging to Srikakulam district.

The three major river basins have the annual water yields of $41.96,22.99$, and 2.79 billion $\mathrm{m}^{3}$. It is estimated that the 37 smaller basins will be contributing 10.755 billion $\mathrm{m}^{3}$ of water annually. Thus the total supply based on $75 \%$ dependability is estimated at 78.51 billion $\mathrm{m}^{3}$ (http://www.apwaterreforms.in).

\section{Data for the Present Study}

5.1. Definition of Variables. This study is based on districtlevel data exclusively drawn from the Government of Andhra Pradesh publications. The following are some of the main features of the data series used.

Basins Coverage. 40 river basins in Andhra Pradesh, where the agriculture sector plays an important role in the economy. 
TABLE 1: Summary statistics: area of the basin and crop output.

\begin{tabular}{|c|c|c|c|c|c|c|c|}
\hline \multirow{2}{*}{ Sl. no. } & \multirow{2}{*}{ Name of the basin } & \multirow{2}{*}{ Area of the basin (ha) } & \multicolumn{4}{|c|}{ Crop output (Rs millions) } & \multirow[b]{2}{*}{$\mathrm{CV}(\%)$} \\
\hline & & & $\operatorname{Max}$ & Min & Average & SD & \\
\hline 1 & Bahuda & 39093 & 172.6 & 16.1 & 126.2 & 36.8 & 31.1 \\
\hline 2 & Mahendratanya & 40273 & 177.8 & 16.1 & 121.7 & 37.9 & 31.2 \\
\hline 3 & Poondi minor drain & 28501 & 125.8 & 14.8 & 86.3 & 26.4 & 30.6 \\
\hline 4 & Naupada minor drain & 71735 & 316.6 & 16.1 & 216.4 & 68.8 & 31.8 \\
\hline 5 & Vamsadhara & 162551 & 717.5 & 16.1 & 489.6 & 158.2 & 32.3 \\
\hline 6 & Nagavali & 526446 & 1297.0 & 15.5 & 985.3 & 307.5 & 31.2 \\
\hline 7 & Pedda Gedda & 31276 & 138.0 & 16.1 & 94.6 & 29.1 & 30.8 \\
\hline 8 & Kandivalasa Gedda & 33317 & 108.7 & 13.1 & 79.0 & 23.5 & 29.7 \\
\hline 9 & Champavathi & 169731 & 337.0 & 20.2 & 213.9 & 67.6 & 31.6 \\
\hline 10 & Gosthani & 156431 & 310.6 & 20.2 & 197.2 & 62.2 & 31.5 \\
\hline 11 & Mathurawada & 32604 & 64.7 & 9.4 & 41.7 & 11.6 & 27.9 \\
\hline 12 & Narva Gedda & 14893 & 29.6 & 4.3 & 19.4 & 5.0 & 25.5 \\
\hline 13 & Anakapalli minor drain & 43709 & 86.8 & 12.5 & 55.6 & 16.1 & 28.9 \\
\hline 14 & Sarada & 291111 & 578.0 & 20.2 & 366.4 & 117.5 & 32.1 \\
\hline 15 & Varaha & 117278 & 232.9 & 20.2 & 148.0 & 46.1 & 31.1 \\
\hline 16 & Tandava & 130327 & 269.4 & 17.8 & 177.9 & 53.7 & 30.2 \\
\hline 17 & Pampa & 52284 & 214.5 & 15.2 & 144.1 & 43.4 & 30.1 \\
\hline 18 & Sudda Gedda & 41794 & 171.5 & 15.2 & 115.3 & 34.4 & 29.8 \\
\hline 19 & Yeleru & 354728 & 1302.5 & 14.2 & 880.9 & 269.5 & 30.6 \\
\hline 20 & Godavari & 7313590 & 20653.0 & 18.8 & 12278.9 & 4180.8 & 34.0 \\
\hline 21 & Errakalava & 503382 & 3431.1 & 14.4 & 2444.4 & 722.7 & 29.6 \\
\hline 22 & Thammileru & 247187 & 1499.7 & 14.3 & 1058.7 & 313.3 & 29.6 \\
\hline 23 & Ramileru & 112659 & 721.2 & 14.2 & 509.7 & 155.7 & 30.6 \\
\hline 24 & Budameru & 521885 & 3305.8 & 15.6 & 2306.7 & 740.6 & 32.1 \\
\hline 25 & Krishna & 7426975 & 20547.9 & 18.0 & 12421.7 & 4184.4 & 33.7 \\
\hline 26 & Romperu & 599158 & 3728.5 & 20.6 & 2167.6 & 748.7 & 34.5 \\
\hline 27 & Gundlakamma & 646428 & 1648.8 & 29.1 & 771.0 & 310.0 & 40.2 \\
\hline 28 & $\begin{array}{l}\text { Minor drain between Musi \& } \\
\text { Gundlakamma }\end{array}$ & 65853 & 168.0 & 24.8 & 79.4 & 29.7 & 37.3 \\
\hline 29 & Musi & 216732 & 552.8 & 29.1 & 259.2 & 102.3 & 39.5 \\
\hline 30 & Paleru & 216321 & 551.7 & 29.1 & 258.7 & 102.1 & 39.5 \\
\hline 31 & Manneru & 340198 & 844.0 & 20.5 & 477.1 & 165.6 & 34.7 \\
\hline 32 & Kandeleru (Chippaleru) & 126376 & 363.3 & 19.5 & 210.4 & 69.6 & 33.1 \\
\hline 33 & Pennar & 5036365 & 9337.3 & 16.6 & 6829.2 & 2168.5 & 31.8 \\
\hline 34 & Upputeru & 329133 & 946.1 & 19.5 & 546.8 & 184.4 & 33.7 \\
\hline 35 & Swarnamukhi & 338602 & 1251.5 & 23.8 & 674.1 & 228.3 & 33.9 \\
\hline 36 & Kalangi & 227090 & 752.6 & 20.2 & 435.9 & 139.5 & 32.0 \\
\hline 37 & Araniar & 70192 & 329.0 & 32.7 & 153.8 & 58.3 & 37.9 \\
\hline 38 & Koratliar & 100042 & 468.9 & 32.7 & 218.8 & 84.1 & 38.5 \\
\hline 39 & Palar & 491630 & 2304.4 & 32.7 & 1070.7 & 424.2 & 39.6 \\
\hline 40 & Ponnair & 38302 & 179.5 & 32.0 & 84.5 & 30.8 & 36.5 \\
\hline
\end{tabular}

Time Period. The study covers 30 years period from 1979-80 to 2008-09.

Output Series. The study uses one-output variables, namely, crops including horticultural crops output variable in value at 1981-82 constant prices. The output series for the variable is derived by aggregating detailed output quantity data of all agricultural commodities listed in Table 1.

Total inputs used in agriculture include land, labor, tractors, pump sets, chemical fertilizers, and irrigated area. 
Labor Input. This variable refers to economically active population in agriculture. Economically active population is defined as all persons engaged or seeking employment in an economic activity, whether as employers, own-account workers, salaried employees, or unpaid workers assisting in the operation of a family farm or business.

Land Input. Land input is measured by area sown rather than arable land because the arable land data is extremely inaccurate. Sown area is land on which crops are planted and from which a harvest is expected. Because land is frequently sown two or even more times a year depending on climate and soil quality, sown area is substantially larger than arable land. Therefore, sown area also indicates land quality more accurately.

Tractors. Total number of tractors used.

Pump Sets. This variable covers the total number of electrical pumpsets used by farmers in the respective river basins.

Chemical Fertilizer Input. Chemical fertilizer includes weights of nitrogen, superphosphate, and potassium sulfate.

Irrigation Input. This data refers to the area of land which is equipped to provide water to crops. The units of variables used are as follows,

output: value in million rupees,

labor: agricultural workers in '000s,

tractors: number of tractors in ' 000 s,

pump sets: number of pump sets in '000s,

chemicals and fertilizers: quantity in ' 000 tonnes,

irrigation input: area in ' 000 hectares.

The present study is of empirical nature and the study is intended to utilize both primary and secondary data for past 30 years from published and unpublished records. Secondary sources for data collection were seasons and crop report, economic appraisal of Andhra Pradesh, publications of Central Water Commission, Published and unpublished records of Public Works Department, Census of India, District Statistical Office, Department of Agriculture, and so forth, and the Internet website http://www.andhrapradeshstat.com.

The data collected for 40 river basins of Andhra Pradesh were area under each basin, district covered under each basin, area of the district, area covered in the basin, percentage of area covered in the district, percentage of area covered in the basin, cropping pattern and cropping calendar, land use pattern, surface water potential, present and future water demand in the basin area, the storage capacity of the existing reservoirs, total command area, number of tanks and their storage capacity. The following data were collected district wise from various published sources for 30 years (from 197980 to 2008-09): production of major crops, input data on gross area sown, gross irrigated area, agricultural laborers and cultivators, number of pumpsets and fertilizer consumption (nitrogen, phosphorus, and potassium). Output data included the area, production of crops, and the price of outputs. Major crops include 14 agricultural crops, namely, rice, sorghum, pearl millet, maize, finger millet, chickpea, pigeonpea, pulses, groundnut, sesamum, castor, oilseeds, sugarcane, and cotton, and 6 horticultural crops, namely, chillies, turmeric, mango, cashew nut, banana, and tomato.

Even though the performance of the basins could also be influenced by other set of environment-related variables such as extent of water quality changes, number of failed wells, degraded lands, level of nonpoint water pollution, and so forth, time series data of these variables are not available and hence not considered for the present study. But this will form the scope for the future studies.

5.2. Conversion of District-Wise Data to Basin-Wise Data. Data on various input and output variables are available district wise for all the 23 districts from published records for the years 1979-80 to 2008-09. These time series figures are then be apportioned to various basins based on the estimates obtained in step 1 as follows: Let $p_{i j}(i=1,2, \ldots B ; j=$ $1,2, \ldots D$ ) be the proportion of area occupied by basin $i$ in district $j$ and $B$ and $D$ be, respectively, the total number of basins and districts. Also let $x d$ be the value of a input or output variable for the district $d$ in an certain year and $y b$ be the estimated value of that variable for basin $b$ during the same year. Also let

$$
Y=\left[\begin{array}{c}
y_{1} \\
y_{2} \\
\cdot \\
\cdot \\
y_{B}
\end{array}\right] \quad X=\left[\begin{array}{c}
x_{1} \\
x_{2} \\
\cdot \\
\cdot \\
x_{D}
\end{array}\right], \quad P=\left[\begin{array}{ccccc}
p_{11} & p_{12} & \cdot & \cdot & p_{1 D} \\
p_{21} & p_{22} & \cdot & \cdot & p_{2 D} \\
\cdot & \cdot & \cdot & \cdot & \cdot \\
\cdot & \cdot & \cdot & \cdot & \cdot \\
p_{B 1} & p_{B 2} & \cdot & \cdot & p_{B D}
\end{array}\right] .
$$

It can be easily checked that

$$
Y=P X
$$

The above formula provides an elegant method of estimation of figures for each basin. This procedure is applied for converting district-wise values of agricultural output, and all inputs to basin-wise figures.

\section{Results and Discussion}

\subsection{Summary Statistics}

6.1.1. Crop Output. The summary statistics of output and input variables, namely, crop output, gross-cropped area, gross-irrigated area, NPK intake, labor input, tractors, and pump sets, are presented and discussed below.

From Table 1 it could be noted that there was wide range of crop outputs in all the river basins. Godavari and Krishna basins which form the major share of basin area, have maximum crop outputs. The coefficient of variation (CV) ranged between 28 to $40 \%$. The minimum percentage corresponds to Mathurawada and maximum corresponds 


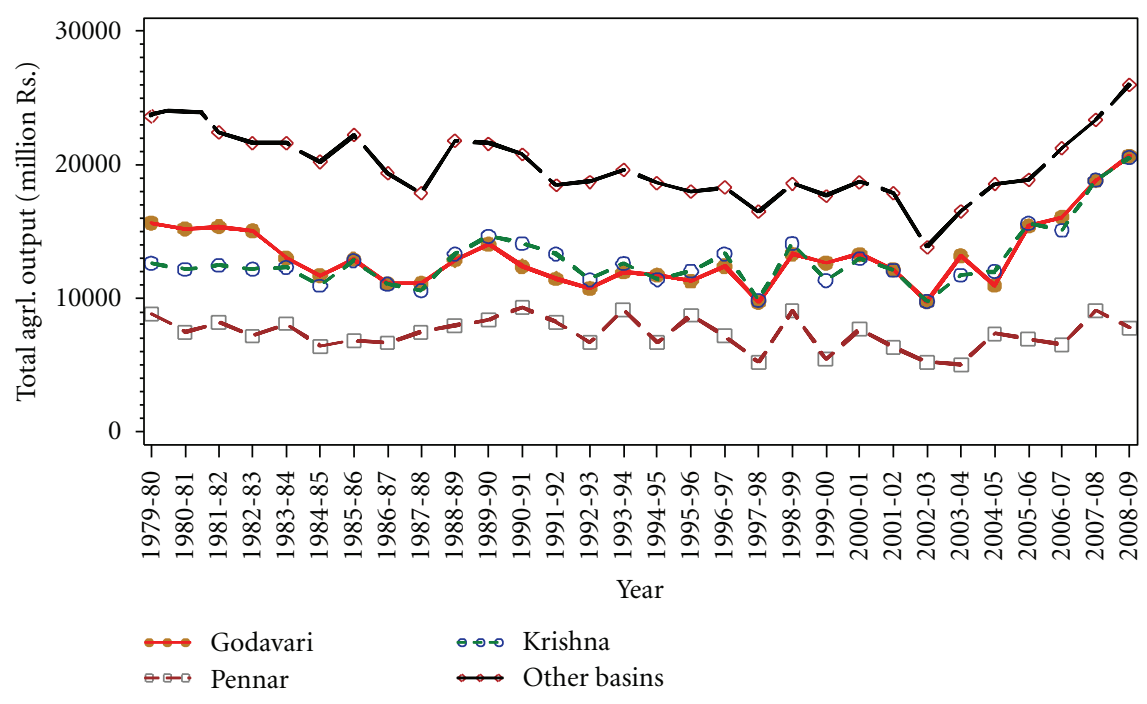

Figure 2: Trend in total Agrl. Outputs in river basins of Andhra Pradesh.

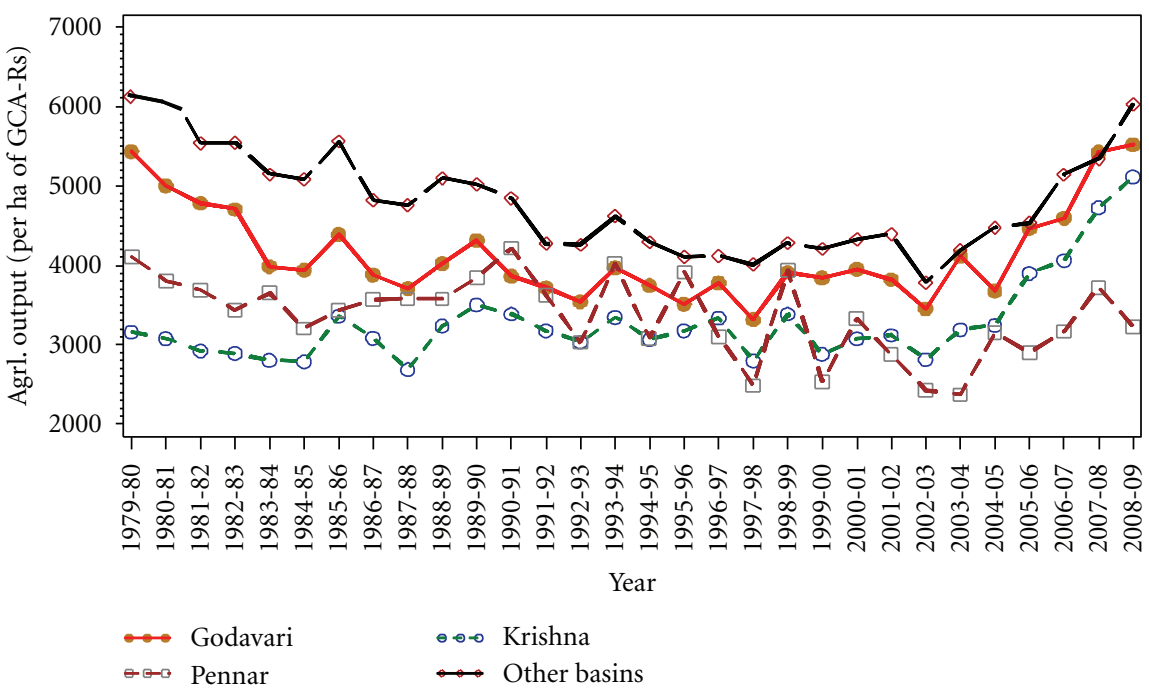

Figure 3: Trend in agricultural output per ha of gross-cropped area.

to Gundlakamma. Godavari, Krishna, and Pennar are the major river basins. The remaining 37 basins are smaller compared to three basins and hence they are grouped under "other basins" category for the purpose of data analysis and interpretation.

The trends in total agricultural output (in million Rs.) (Figure 2) indicates that of the three major river basins, Krishna and Godavari basins contribute more or less equally in all the years from 1984-85. The contribution of the Pennar basin with an area roughly equal to $70 \%$ of the Godavari basin area is very much lesser compared to the other two major river basins throughout the study period. The contribution of all other 37 basins with an expected annual water yield of only $6.65 \%$ of Godavari basin is very much higher in the entire three decades.

Since the gross agricultural output is very much dependent on gross-cropped area, gross-irrigated area and also water yield in the basin, an analysis was carried out to study the trend in the agricultural output (in Rs.) per unit of the above factors. The trends are depicted in Figures 3, 4, and 5 .

\subsubsection{Total Agricultural Output per ha of Gross-Cropped Area.} This is obtained by dividing the total agricultural output of the respective basin in each year by the -ropped area of the basin in the same year. The trend shows that the contribution from the 37 basins is uniformly higher than the three major river basins. Further, Godavari basin has higher agricultural output per ha of gross-cropped area compared to Krishna and Pennar basins. The performance of Krishna basin is the least in most of the initial periods and picked up during later years.

6.1.3. Total Agricultural Output per ha of Gross-Irrigated Area. The trend indicates that per ha gross-irrigated area output is 


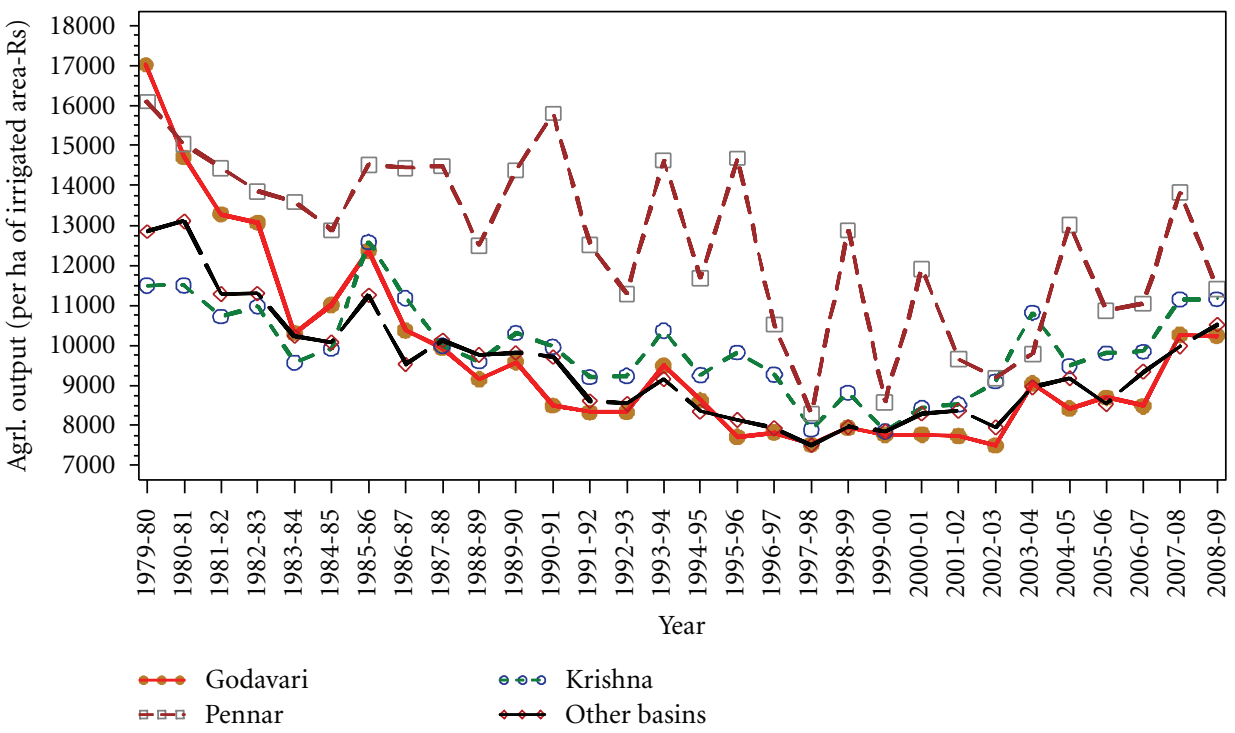

FIgURE 4: Trend in output per hectare of GIA.

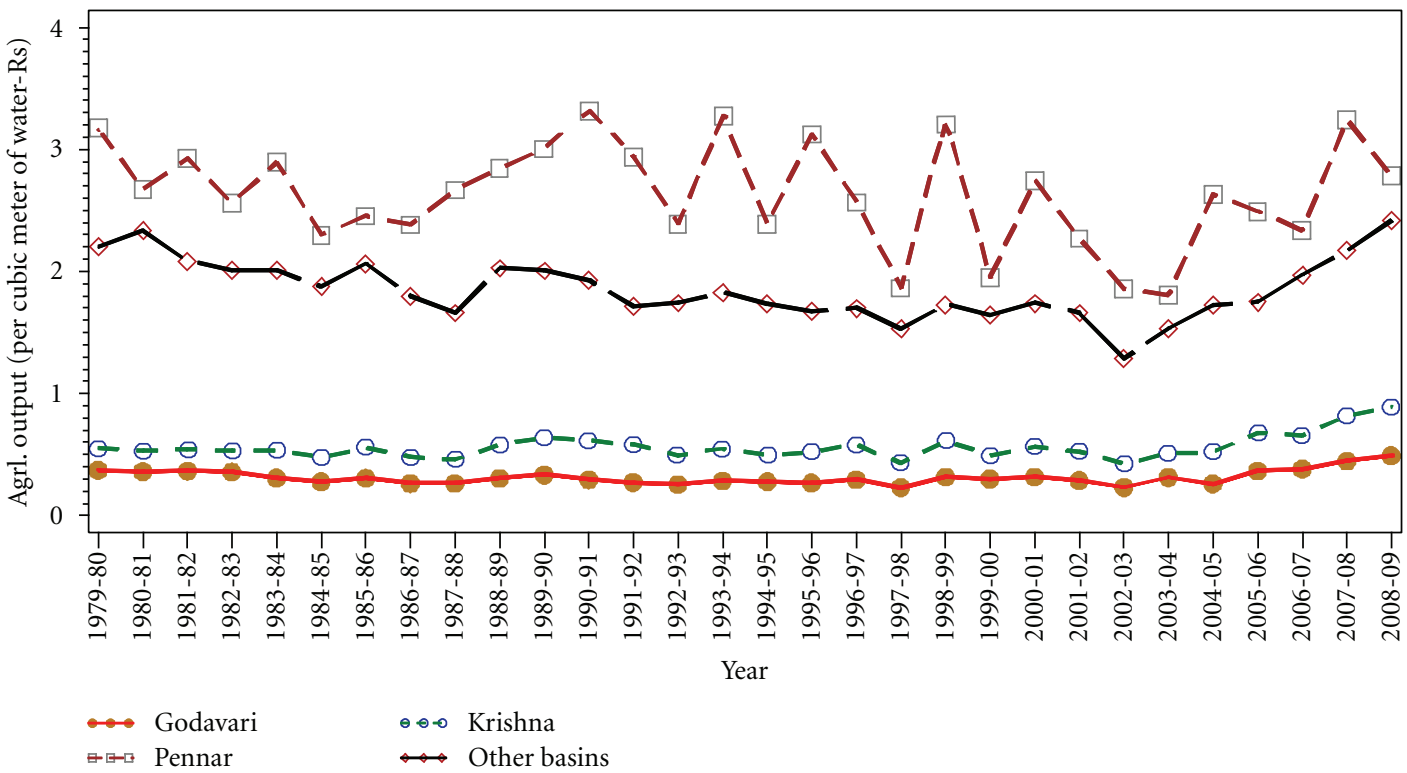

FIgURE 5: Total agricultural output per cubic meter of water.

maximum for Pennar basin followed by Krishna basin. This shows that it will be highly beneficial to increase irrigated area in those two basins.

It was already pointed out that Godavari, Krishna, Pennar, and other basins, respectively, have the 41.96 billion $\mathrm{m}^{3}$, 22.99 billion $\mathrm{m}^{3}, 2.79$ billion $\mathrm{m}^{3}$, and 10.755 billion $\mathrm{m}^{3}$ water yield per year. Assuming that this much quantity of water was available in the basins in each year of the study period, the gross agricultural output per cubic meter of water was computed (Figure 5). The trend analysis indicates that Pennar basin has the maximum potential to generate output per cubic meter of water followed by other basins and Krishna basin.
6.1.4. Inputs. The study used gross-cropped area, grossirrigated area, NPK consumption, agricultural labourers, tractors, and pumpsets as inputs. Tables 2(a)-2(f) provide the summary statistics of all these inputs for every 10 years and also for the 30 years of the study period.

6.2. Technical Efficiency of the River Basins. The results of the average technical efficiency (output oriented) of the 40 river basins are presented in Table 3. The averages are the geometric mean for 30 years of the technical efficiencies of the respective river basins. The average technical efficiency works out 0.658 which implies that only $65.8 \%$ of the possible outputs have been produced by the basins using 
TABle 2

(a) Gross-cropped area (thousand ha)

\begin{tabular}{|c|c|c|c|c|c|c|c|c|c|c|}
\hline \multirow{2}{*}{ Basin name } & \multicolumn{5}{|c|}{ 1979-1988 } & \multicolumn{5}{|c|}{ 1989-1998 } \\
\hline & Max & Min & Average & S.D. & C.V. (\%) & $\operatorname{Max}$ & Min & Average & S.D. & C.V. (\%) \\
\hline Godavari & 3263.62 & 2857.71 & 3056.21 & 47.44 & 1.55 & 3405.66 & 2930.00 & 3156.15 & 45.68 & 1.45 \\
\hline Krishna & 4403.71 & 3581.92 & 4022.24 & 2.35 & 0.06 & 4199.98 & 3528.94 & 3928.91 & 2.35 & 0.06 \\
\hline Pennar & 2225.40 & 1868.92 & 2082.15 & 0.82 & 0.04 & 2308.57 & 2093.20 & 2224.23 & 0.82 & 0.04 \\
\hline Other basins & 4275.31 & 3751.58 & 4001.85 & 1.58 & 0.04 & 4440.75 & 4110.92 & 4318.86 & 1.58 & 0.04 \\
\hline \multirow{2}{*}{ Basin name } & \multicolumn{5}{|c|}{ 1999-2008 } & \multicolumn{5}{|c|}{ 1979-2008 } \\
\hline & Max & Min & Average & S.D. & C.V. $(\%)$ & Max & Min & Average & S.D. & C.V. (\%) \\
\hline Godavari & 3742.87 & 2826.92 & 3300.63 & 84.11 & 2.55 & 3742.87 & 2826.92 & 3171.00 & 39.08 & 1.23 \\
\hline Krishna & 4212.28 & 3474.27 & 3860.90 & 2.35 & 0.06 & 4403.71 & 3474.27 & 3937.35 & 2.35 & 0.06 \\
\hline Pennar & 2431.75 & 2063.03 & 2259.93 & 0.82 & 0.04 & 2431.75 & 1868.92 & 2188.77 & 0.82 & 0.04 \\
\hline Other basins & 4376.33 & 3658.66 & 4131.60 & 1.58 & 0.04 & 4440.75 & 3658.66 & 4150.77 & 1.58 & 0.04 \\
\hline
\end{tabular}

(b) Gross-irrigated area (thousand ha)

\begin{tabular}{|c|c|c|c|c|c|c|c|c|c|c|}
\hline \multirow{2}{*}{ Basin name } & \multicolumn{5}{|c|}{ 1979-1988 } & \multicolumn{5}{|c|}{ 1989-1998 } \\
\hline & Max & Min & Average & S.D. & C.V. (\%) & Max & Min & Average & S.D. & C.V. (\%) \\
\hline Godavari & 1404.31 & 919.17 & 1121.66 & 42.53 & 3.79 & 1675.09 & 1260.15 & 1421.75 & 42.51 & 2.99 \\
\hline Krishna & 1389.54 & 986.92 & 1127.02 & 2.35 & 0.21 & 1598.09 & 1215.24 & 1347.43 & 2.35 & 0.17 \\
\hline Pennar & 636.89 & 461.22 & 530.91 & 0.82 & 0.15 & 704.00 & 571.18 & 622.53 & 0.82 & 0.13 \\
\hline Other basins & 2233.55 & 1762.68 & 1977.54 & 1.58 & 0.08 & 2333.35 & 2135.62 & 2208.87 & 1.58 & 0.07 \\
\hline \multirow{2}{*}{ Basin name } & \multicolumn{5}{|c|}{ 1999-2008 } & \multicolumn{5}{|c|}{ 1979-2008 } \\
\hline & Max & Min & Average & S.D. & C.V. $(\%)$ & Max & Min & Average & S.D. & C.V. (\%) \\
\hline Godavari & 2015.35 & 1300.52 & 1647.02 & 76.84 & 4.67 & 2015.35 & 919.17 & 1396.81 & 50.81 & 3.64 \\
\hline Krishna & 1839.88 & 1073.38 & 1446.91 & 2.35 & 0.16 & 1839.88 & 986.92 & 1307.12 & 2.35 & 0.18 \\
\hline Pennar & 680.88 & 516.52 & 615.20 & 0.82 & 0.13 & 704.00 & 461.22 & 589.55 & 0.82 & 0.14 \\
\hline Other basins & 2469.26 & 1740.51 & 2152.39 & 1.58 & 0.07 & 2469.26 & 1740.51 & 2112.93 & 1.58 & 0.07 \\
\hline
\end{tabular}

(c) NPK consumption (thousand Tonnes)

\begin{tabular}{|c|c|c|c|c|c|c|c|c|c|c|}
\hline \multirow{2}{*}{ Basin name } & \multicolumn{5}{|c|}{ 1979-1988 } & \multicolumn{5}{|c|}{ 1989-1998 } \\
\hline & Max & Min & Average & S.D. & C.V. (\%) & Max & Min & Average & S.D. & C.V. (\%) \\
\hline Godavari & 284.70 & 88.53 & 164.04 & 17.62 & 10.74 & 464.55 & 320.80 & 367.09 & 13.74 & 3.74 \\
\hline Krishna & 401.15 & 153.73 & 242.81 & 2.35 & 0.97 & 670.17 & 450.33 & 520.03 & 2.35 & 0.45 \\
\hline Pennar & 133.23 & 55.00 & 78.15 & 0.82 & 1.04 & 214.37 & 149.17 & 179.44 & 0.82 & 0.45 \\
\hline Other basins & 556.33 & 207.91 & 337.43 & 1.58 & 0.47 & 749.10 & 558.80 & 624.39 & 1.58 & 0.25 \\
\hline \multirow{2}{*}{ Basin name } & \multicolumn{5}{|c|}{ 1999-2008 } & \multicolumn{5}{|c|}{ 1979-2008 } \\
\hline & Max & Min & Average & S.D. & C.V. (\%) & Max & Min & Average & S.D. & C.V. (\%) \\
\hline Godavari & 806.90 & 409.77 & 537.00 & 37.91 & 7.06 & 806.90 & 88.53 & 356.04 & 31.65 & 8.89 \\
\hline Krishna & 950.54 & 494.99 & 721.30 & 2.35 & 0.33 & 950.54 & 153.73 & 494.71 & 2.35 & 0.47 \\
\hline Pennar & 351.11 & 187.66 & 243.02 & 0.82 & 0.34 & 351.11 & 55.00 & 166.87 & 0.82 & 0.49 \\
\hline Other basins & 1045.19 & 569.70 & 794.76 & 1.58 & 0.20 & 1045.19 & 207.91 & 585.53 & 1.58 & 0.27 \\
\hline
\end{tabular}

(d) Agricultural labourers (thousand workers)

\begin{tabular}{|c|c|c|c|c|c|c|c|c|c|c|}
\hline \multirow{2}{*}{ Basin name } & \multicolumn{5}{|c|}{ 1979-1988 } & \multicolumn{5}{|c|}{ 1989-1998 } \\
\hline & Max & Min & Average & S.D. & C.V. $(\%)$ & Max & Min & Average & S.D. & C.V. (\%) \\
\hline Godavari & 4463.16 & 3828.02 & 4163.76 & 206.76 & 4.97 & 5196.66 & 4531.24 & 4856.70 & 223.84 & 4.61 \\
\hline Krishna & 5036.67 & 4219.71 & 4640.87 & 267.75 & 5.77 & 6032.33 & 5132.10 & 5569.10 & 302.82 & 5.44 \\
\hline Pennar & 2762.68 & 2452.69 & 2623.59 & 98.05 & 3.74 & 3125.97 & 2798.47 & 2954.00 & 110.20 & 3.73 \\
\hline Other basins & 6360.26 & 5411.19 & 5912.69 & 300.68 & 5.09 & 7444.38 & 6515.70 & 6938.34 & 313.70 & 4.52 \\
\hline \multirow{2}{*}{ Basin name } & \multicolumn{5}{|c|}{ 1999-2008 } & \multicolumn{5}{|c|}{ 1979-2008 } \\
\hline & Max & Min & Average & S.D. & C.V. $(\%)$ & Max & Min & Average & S.D. & C.V. $(\%)$ \\
\hline Godavari & 6061.21 & 5276.83 & 5660.37 & 263.85 & 4.66 & 6061.21 & 5441.20 & 5746.07 & 216.96 & 3.78 \\
\hline Krishna & 7231.41 & 6146.75 & 6675.85 & 364.34 & 5.46 & 7231.41 & 6367.81 & 6793.44 & 301.10 & 4.43 \\
\hline
\end{tabular}


(d) Continued.

\begin{tabular}{|c|c|c|c|c|c|c|c|c|c|c|}
\hline \multirow{2}{*}{ Basin name } & \multicolumn{5}{|c|}{ 1979-1988 } & \multicolumn{5}{|c|}{ 1989-1998 } \\
\hline & Max & Min & Average & S.D. & C.V. (\%) & Max & Min & Average & S.D. & C.V. (\%) \\
\hline Pennar & 3606.59 & 3172.57 & 3381.83 & 145.49 & 4.30 & 3606.59 & 3255.39 & 3428.05 & 121.82 & 3.55 \\
\hline Other basins & 8791.60 & 7627.92 & 8195.71 & 387.49 & 4.73 & 8791.60 & 7801.86 & 8312.64 & 334.75 & 4.03 \\
\hline
\end{tabular}

(e) Tractors (thousands)

\begin{tabular}{|c|c|c|c|c|c|c|c|c|c|c|}
\hline \multirow{2}{*}{ Basin name } & \multicolumn{5}{|c|}{ 1979-1988 } & \multicolumn{5}{|c|}{ 1989-1998 } \\
\hline & Max & Min & Average & S.D. & C.V. $(\%)$ & Max & Min & Average & S.D. & C.V. $(\%)$ \\
\hline Godavari & 7.73 & 3.08 & 5.37 & 0.47 & 8.69 & 19.45 & 8.61 & 13.75 & 1.15 & 8.37 \\
\hline Krishna & 9.93 & 4.02 & 6.45 & 2.35 & 36.39 & 24.43 & 11.32 & 18.15 & 2.35 & 12.93 \\
\hline Pennar & 5.26 & 2.07 & 3.49 & 0.82 & 23.38 & 13.51 & 5.97 & 9.74 & 0.82 & 8.38 \\
\hline Other basins & 17.04 & 8.04 & 12.22 & 1.58 & 12.91 & 34.67 & 18.90 & 26.79 & 1.58 & 5.89 \\
\hline \multirow{2}{*}{ Basin name } & \multicolumn{5}{|c|}{ 1999-2008 } & \multicolumn{5}{|c|}{ 1979-2008 } \\
\hline & Max & Min & Average & S.D. & C.V. (\%) & Max & Min & Average & S.D. & C.V. (\%) \\
\hline Godavari & 32.44 & 20.95 & 25.44 & 1.22 & 4.79 & 32.44 & 3.08 & 14.86 & 1.63 & 10.96 \\
\hline Krishna & 52.22 & 25.65 & 33.97 & 2.35 & 6.91 & 52.22 & 4.02 & 19.52 & 2.35 & 12.02 \\
\hline Pennar & 14.56 & 13.09 & 13.51 & 0.82 & 6.04 & 14.56 & 2.07 & 8.91 & 0.82 & 9.16 \\
\hline Other basins & 37.02 & 23.08 & 28.65 & 1.58 & 5.50 & 37.02 & 8.04 & 22.55 & 1.58 & 6.99 \\
\hline
\end{tabular}

(f) Pump sets (thousands)

\begin{tabular}{|c|c|c|c|c|c|c|c|c|c|c|}
\hline \multirow{2}{*}{ Basin name } & \multicolumn{5}{|c|}{ 1979-1988 } & \multicolumn{5}{|c|}{ 1989-1998 } \\
\hline & Max & Min & Average & S.D. & C.V. $(\%)$ & Max & Min & Average & S.D. & C.V. (\%) \\
\hline Godavari & 311.52 & 172.97 & 249.35 & 14.47 & 5.80 & 430.47 & 324.77 & 381.42 & 10.89 & 2.86 \\
\hline Krishna & 280.19 & 165.38 & 223.24 & 2.35 & 1.05 & 402.10 & 296.80 & 358.63 & 2.35 & 0.65 \\
\hline Pennar & 154.74 & 107.00 & 130.69 & 0.82 & 0.62 & 182.07 & 155.97 & 166.99 & 0.82 & 0.49 \\
\hline Other Basins & 231.43 & 155.09 & 186.27 & 1.58 & 0.85 & 280.90 & 245.18 & 271.67 & 1.58 & 0.58 \\
\hline \multirow{2}{*}{ Basin name } & \multicolumn{5}{|c|}{ 1999-2008 } & \multicolumn{5}{|c|}{ 1979-2008 } \\
\hline & Max & Min & Average & S.D. & C.V. $(\%)$ & Max & Min & Average & S.D. & C.V. (\%) \\
\hline Godavari & 658.66 & 442.84 & 540.53 & 22.91 & 4.24 & 658.66 & 172.97 & 390.43 & 24.02 & 6.15 \\
\hline Krishna & 1193.52 & 412.19 & 716.80 & 2.35 & 0.33 & 1193.52 & 165.38 & 432.89 & 2.35 & 0.54 \\
\hline Pennar & 186.34 & 155.92 & 163.36 & 0.82 & 0.50 & 186.34 & 107.00 & 153.68 & 0.82 & 0.53 \\
\hline Other basins & 315.62 & 283.34 & 296.61 & 1.58 & 0.53 & 315.62 & 155.09 & 251.52 & 1.58 & 0.63 \\
\hline
\end{tabular}

the current level of inputs. The first three ranks of the efficiencies are occupied by Manneru (0.879), Upputeru (0.837), and Kandeleru (0.827). Surprisingly the major river basins, namely, Godavari, Krishan, occupy only 32nd and 15th ranks while the third largest basin Pennar has rank 4. It can be seen that the basins with first six ranks are adjacent to each other. Similarly the basins with last three ranks are neighbouring basins, namely, Gosthani (0.479), Kandivalasa Gedda (0.503), and Pedda Gedda (0.504). The average of these efficiencies works out to 0.495 . This means that if the available inputs in these basins are utilized optimally the output can be expanded by $198 \%$ with given inputs and technology recommended in the region. Thus steps must be taken to improve the technical efficiency in these regions to increase agricultural productivity.

Annual compound growth rates of inputs and agricultural output are provided in Table 4 . In all the basins there was a decline in growth of agricultural output during the first two decades, namely, $1979-80$ to $1988-89$, and it had picked in the last decade only. Krishna basin has the highest growth rate $(6.57 \%)$ followed by Godavari $(5.875 \%)$ during this period. There is not much increase in gross-cropped areas in all the basins and the performance is slightly better only in 1999-00 to 2008-09. In contrast, gross-irrigated area has a better performance in all the periods and in all the basins. In fact Krishna and Godavari basins show highest annual growth rates. Growth rate of labour stabilized around $1.5 \%$ in all the basins. Fertilizer consumption showed a growth rate of $5 \%$ in all the basins. Similar trend existed in terms of the other two inputs, namely, tractors and pumpsets except at Pennar basin where there is a decline in the growth rate of these inputs during the last decade. Thus the variation in output and inputs growth rates had clearly indicated that other than the physical inputs, other noninputs factors also contributed for the output growth. Hence analysis of the total factor productivity is discussed below.

6.3. Total Factor Productivity (TFP). Total factor productivity analysis using Malmquist index was carried out for all the 40 river basins. Table 6 gives the results of TFP analysis. 
TABle 3: Technical efficiency (TE) of river basins.

\begin{tabular}{|c|c|c|}
\hline Basin & $\mathrm{TE}$ & Rank \\
\hline Bahuda & 0.617 & 24 \\
\hline Mahendratanya & 0.559 & 33 \\
\hline Poondi minor drain & 0.553 & 34 \\
\hline Naupada minor drain & 0.560 & 32 \\
\hline Vamsadhara & 0.534 & 35 \\
\hline Nagavali & 0.515 & 36 \\
\hline Pedda Gedda & 0.504 & 38 \\
\hline Kandivalasa Gedda & 0.503 & 39 \\
\hline Champavathi & 0.508 & 37 \\
\hline Gosthani & 0.479 & 40 \\
\hline Mathurawada & 0.614 & 26 \\
\hline Narva Gedda & 0.611 & 28 \\
\hline Anakapalli minor drain & 0.621 & 22 \\
\hline Sarada & 0.655 & 21 \\
\hline Varaha & 0.615 & 25 \\
\hline Tandava & 0.613 & 27 \\
\hline Pampa & 0.607 & 29 \\
\hline Sudda Gedda & 0.602 & 30 \\
\hline Yeleru & 0.620 & 23 \\
\hline Godavari & 0.574 & 31 \\
\hline Errakalava & 0.747 & 11 \\
\hline Thammileru & 0.725 & 14 \\
\hline Ramileru & 0.738 & 13 \\
\hline Budameru & 0.779 & 8 \\
\hline Krishna & 0.725 & 15 \\
\hline Romperu & 0.714 & 16 \\
\hline Gundlakamma & 0.709 & 17 \\
\hline $\begin{array}{l}\text { Minor drain between Musi \& } \\
\text { Gundlakamma }\end{array}$ & 0.699 & 19 \\
\hline Musi & 0.700 & 18 \\
\hline Paleru & 0.662 & 20 \\
\hline Manneru & 0.879 & 1 \\
\hline Kandeleru (Chippaleru) & 0.827 & 3 \\
\hline Pennar & 0.823 & 4 \\
\hline Upputeru & 0.837 & 2 \\
\hline Swarnamukhi & 0.798 & 5 \\
\hline Kalangi & 0.786 & 6 \\
\hline Araniar & 0.777 & 9 \\
\hline Koratliar & 0.769 & 10 \\
\hline Palar & 0.781 & 7 \\
\hline Ponnair & 0.738 & 12 \\
\hline Average & 0.658 & \\
\hline
\end{tabular}

6.3.1. Technical Efficiency Change. This refers to movement of the river basins towards the frontier over time capturing the catch-up phenomena. It relates to how the basins have performed relative to the best practice frontier. An efficiency change greater than 1 implies that the basin is operating closer to the frontier than in previous period while the figure less than 1 implies that the basin is operating farther from the frontier. This component compares the distances of the two observations $\left(x_{t}, y_{t}\right)$ and $\left(x_{t+1}, y_{t+1}\right)$ to the corresponding production frontiers. There are 26 river basins whose technical efficiency changes are greater than 1 . This means that these river basins have moved closer to the frontier than in the previous year. For example, the technical efficiency change of Godavari basin is 1.029 . This means that if the distance between the performance of the basin and the frontier basin in current year is $d$, then in next year the distance between the basin and the production frontier (of the next year) becomes $d / 1.029=0.972 d$. In other word the basin's performance is improving and moving towards frontier.

There are 14 river basins which have technical efficiency change less than 1 (Table 5).

These basins are moving away from the frontier basins every year. For example, consider the Bahuda basin whose technical efficiency change is 0.959 . This means that if the distance between the performance of the basin and the frontier basin in current year is $d$, then in next year the distance between the basin and the production frontier (of the next year) becomes $d / 0.959=1.043 d$. In other words, the basin's performance is deteriorating and moving away from the frontier every year. Similar interpretation can be given for the technical efficiency changes of the other basins.

6.3.2. Technical Change. This information on changes in technical efficiency only tells the "catch-up" part of the productivity story. TFP change can also appear in the form of technical change (or frontier shift). This refers to shift of the best practice frontier capturing innovations. This is affected by new technologies in agricultural or new innovations like high yielding varieties or also changes in the economic policies and regulations on the environment. According to the result presented in Table 5, all the 40 river basins have technology change greater than 1 implying that there is shift in production frontier over years. This shows the effectiveness of use of modern technology in agriculture in Andhra Pradesh.

The total factor productivity change is an important yardstick. All the river basins have TFP change greater than 1 (Figure 6) indicating progress in agricultural productivity in all the basins. The TFP changes can be used to rank the individual basins and they are given in the last column of Table 6. It is clear that Madurawada basin with a TFP change of 1.259 occupies the first rank and Bahuda basin whose TFP change is 1.051 occupies the last rank. Thus the agricultural performance of Madurawada river basin can be used as yardstick to compare the performances of other basins. Those river basins that have low TFP change can improve their productivity by following the cropping practice such as cropping pattern, crop variety, and so forth of Madurawada river basin. In the case of the three major river basins, the ranks of Godavari, Krishna, and Pennar basins are, respectively, 8,26 , and 23 with respective TFP indices being $1.211,1.152$, and 1.169 . This indicates that Godavari basin's performance is slightly better in comparison 
TABLE 4: Annual growth rates in inputs and outputs in river basins of Andhra Pradesh.

\begin{tabular}{|c|c|c|c|c|c|}
\hline & Period & Godavari & Krishna & Pennar & Other basins \\
\hline \multirow{4}{*}{ Output } & $1979-80$ to $88-89$ & -3.655 & -0.645 & -1.420 & -2.320 \\
\hline & $1989-90$ to $98-99$ & -0.994 & -1.667 & -2.144 & -1.909 \\
\hline & $1999-00$ to $2008-09$ & 5.875 & 6.570 & 3.557 & 4.286 \\
\hline & $1979-80$ to $2008-09$ & 0.250 & 0.714 & -0.535 & -0.555 \\
\hline \multicolumn{6}{|l|}{ Inputs } \\
\hline \multirow{4}{*}{ Gross-cropped area } & $1979-80$ to $88-89$ & -0.052 & -0.628 & -0.227 & 0.258 \\
\hline & $1989-90$ to $98-99$ & 0.189 & -0.862 & 0.095 & -0.024 \\
\hline & $1999-00$ to $2008-09$ & 1.439 & 0.000 & 0.913 & 0.509 \\
\hline & $1979-80$ to $2008-09$ & 0.392 & -0.236 & 0.394 & 0.167 \\
\hline \multirow{4}{*}{ Gross-irrigated area } & $1979-80$ to $88-89$ & 2.146 & 0.541 & 0.060 & 0.779 \\
\hline & $1989-90$ to $98-99$ & 0.929 & 0.094 & 1.356 & 0.704 \\
\hline & $1999-00$ to $2008-09$ & 2.553 & 2.807 & 0.424 & 1.348 \\
\hline & $1979-80$ to $2008-09$ & 1.915 & 1.205 & 0.731 & 0.467 \\
\hline \multirow{4}{*}{ Labour } & $1979-80$ to $88-89$ & 1.656 & 1.928 & 1.237 & 1.691 \\
\hline & $1989-90$ to $98-99$ & 1.534 & 1.812 & 1.237 & 1.493 \\
\hline & $1999-00$ to $2008-09$ & 1.552 & 1.819 & 1.430 & 1.559 \\
\hline & $1979-80$ to $2008-09$ & 1.551 & 1.837 & 1.279 & 1.640 \\
\hline \multirow{4}{*}{ Fertilizer consumption } & $1979-80$ to $88-89$ & 10.051 & 8.655 & 6.264 & 10.786 \\
\hline & $1989-90$ to $98-99$ & 2.893 & 3.965 & 2.896 & 2.116 \\
\hline & $1999-00$ to $2008-09$ & 4.893 & 4.911 & 4.591 & 4.190 \\
\hline & $1979-80$ to $2008-09$ & 6.230 & 5.711 & 5.766 & 4.668 \\
\hline \multirow{4}{*}{ Tractors } & $1979-80$ to $88-89$ & 9.987 & 10.408 & 10.435 & 8.294 \\
\hline & $1989-90$ to $98-99$ & 9.389 & 8.484 & 9.161 & 6.793 \\
\hline & $1999-00$ to $2008-09$ & 4.929 & 8.394 & -1.040 & -5.394 \\
\hline & $1979-80$ to $2008-09$ & 8.213 & 8.760 & 7.084 & 4.269 \\
\hline \multirow{4}{*}{ Pumpsets } & $1979-80$ to $88-89$ & 6.447 & 5.799 & 4.506 & 4.736 \\
\hline & $1989-90$ to $98-99$ & 3.045 & 3.189 & 1.793 & 1.256 \\
\hline & 1999-00 to 2008-09 & 4.505 & 12.589 & -1.142 & 1.093 \\
\hline & $1979-80$ to $2008-09$ & 4.060 & 5.913 & 1.214 & 2.392 \\
\hline
\end{tabular}

with the other two basins. This is further confirmed by computing the cumulative TFP index which is arrived by dividing the TFP index of the basin for the year by the TFP index of the base year for that basin (Table 7).

In terms of cumulative TFP indices, Godavari and Pennar basins have much higher values than others. Table 7 summarizes the ranks of the basins based on cumulative TFP indices.

Out of the 28 years, in terms of cumulative TFP indices, Godavari basin ranked 1, 14 times, while Pennar ranked 1, 12 times. Krishna basin ranked 4, 22 times. It was already pointed out that in terms of absolute values of TFP indices Godavari and Pennar have slightly better performance than Krishna. Thus these two basins have performed better than Krishna basin in terms of total factor productivity growth. Table 8 provides the annual growth rate of TFP and its components for the basins. Using the growth rates, the contribution of the TFP and inputs to the total outputs was computed and given in Table 9.

Table 9 captures the contribution of total factor productivity in agricultural growth in the river basins. The contribution to agricultural growth during the first decade
(1979-80 to 88-89) in all basins (except Pennar) and during the third decade (1999-00 to 2008-09) is mainly from total factor productivity and the contribution from inputs is negative during these periods.

During the second decade (1989-90 to 98-99), the contribution is from inputs only and TFP growth has negative contribution. During the three decades, in Godavari basin, agricultural growth is mostly due to TFP growth. In the remaining basins, contribution of inputs is about $101 \%$ to $103 \%$. Further, in general, given the contribution of TFP, the share of efficiency change is dominated by technical change in all the periods and in all the basins (Figure 7).

\section{Conclusions}

Krishna and Godavari basins contribute more or less equally to total agricultural output in all the years from 198485 . With an expected annual water yield of only $6.65 \%$ of Godavari basin, the 37 basins have contributed much higher output in the entire three decades. Among the major basins, Godavari basin has higher agricultural output per ha of gross-cropped area compared to Krishna and Pennar 
TABLE 5: Total factor productivity changes in river basins.

\begin{tabular}{|c|c|c|c|c|}
\hline Basin & Efficiency change & Technical change & TFP change & Rank in terms of TFP change \\
\hline Bahuda & 0.959 & 1.096 & 1.051 & 40 \\
\hline Mahendratanya & 0.958 & 1.112 & 1.065 & 39 \\
\hline Poondi minor drain & 0.961 & 1.118 & 1.074 & 38 \\
\hline Naupada minor drain & 0.967 & 1.138 & 1.1 & 37 \\
\hline Vamsadhara & 0.969 & 1.141 & 1.106 & 34 \\
\hline Nagavali & 0.963 & 1.149 & 1.107 & 32 \\
\hline Pedda Gedda & 0.962 & 1.149 & 1.105 & 35 \\
\hline Kandivalasa Gedda & 0.96 & 1.164 & 1.118 & 30 \\
\hline Champavathi & 0.956 & 1.158 & 1.107 & 32 \\
\hline Gosthani & 0.959 & 1.16 & 1.112 & 31 \\
\hline Mathurawada & 1.028 & 1.226 & 1.259 & 1 \\
\hline Narva Gedda & 1.027 & 1.206 & 1.239 & 2 \\
\hline Anakapalli minor drain & 1.029 & 1.191 & 1.226 & 3 \\
\hline Sarada & 1.029 & 1.189 & 1.224 & 4 \\
\hline Varaha & 1.029 & 1.187 & 1.221 & 5 \\
\hline Tandava & 1.029 & 1.178 & 1.212 & 7 \\
\hline Pampa & 1.027 & 1.184 & 1.216 & 6 \\
\hline Sudda Gedda & 1.029 & 1.17 & 1.205 & 9 \\
\hline Yeleru & 1.028 & 1.168 & 1.202 & 11 \\
\hline Godavari & 1.029 & 1.178 & 1.211 & 8 \\
\hline Errakalava & 1.027 & 1.071 & 1.101 & 36 \\
\hline Thammileru & 1.025 & 1.095 & 1.122 & 29 \\
\hline Ramileru & 1.028 & 1.106 & 1.137 & 27 \\
\hline Budameru & 1.021 & 1.112 & 1.136 & 28 \\
\hline Krishna & 1.027 & 1.122 & 1.152 & 26 \\
\hline Romperu & 1.03 & 1.136 & 1.17 & 22 \\
\hline Gundlakamma & 1.029 & 1.145 & 1.178 & 18 \\
\hline $\begin{array}{l}\text { Minor drain between Musi \& } \\
\text { Gundlakamma }\end{array}$ & 1.03 & 1.169 & 1.204 & 10 \\
\hline Musi & 1.033 & 1.16 & 1.198 & 15 \\
\hline Paleru & 1.029 & 1.167 & 1.201 & 12 \\
\hline Manneru & 0.998 & 1.164 & 1.162 & 25 \\
\hline Kandeleru (Chippaleru) & 0.998 & 1.17 & 1.167 & 24 \\
\hline Pennar & 0.999 & 1.171 & 1.169 & 23 \\
\hline Upputeru & 1.001 & 1.176 & 1.177 & 19 \\
\hline Swarnamukhi & 1.001 & 1.171 & 1.173 & 21 \\
\hline Kalangi & 1.000 & 1.177 & 1.177 & 19 \\
\hline Araniar & 1.001 & 1.185 & 1.186 & 17 \\
\hline Koratliar & 1.003 & 1.195 & 1.199 & 14 \\
\hline Palar & 0.999 & 1.194 & 1.193 & 16 \\
\hline Ponnair & 1.003 & 1.198 & 1.201 & 12 \\
\hline
\end{tabular}

basins. The total agricultural output per ha of gross-irrigated area and output per cubic meter of water are maximum for Pennar basin followed by Krishna basin.

Average technical efficiency of all the basins is only $66 \%$ implying that only $66 \%$ of the maximum possible outputs have been produced by the basins using the current level of inputs. The first three ranks of the efficiencies are occupied by other basins, namely, Manneru (0.879), Upputeru (0.837) and Kandeleru (0.827), and Godavari and Krishna with respective efficiencies of 0.574 and 0.725 occupy 32nd and 15th ranks, while the third largest basin Pennar with an efficiency of 0.823 has rank 4 .

In all the basins there was a decline in growth of agricultural output during the first two decades, namely, 


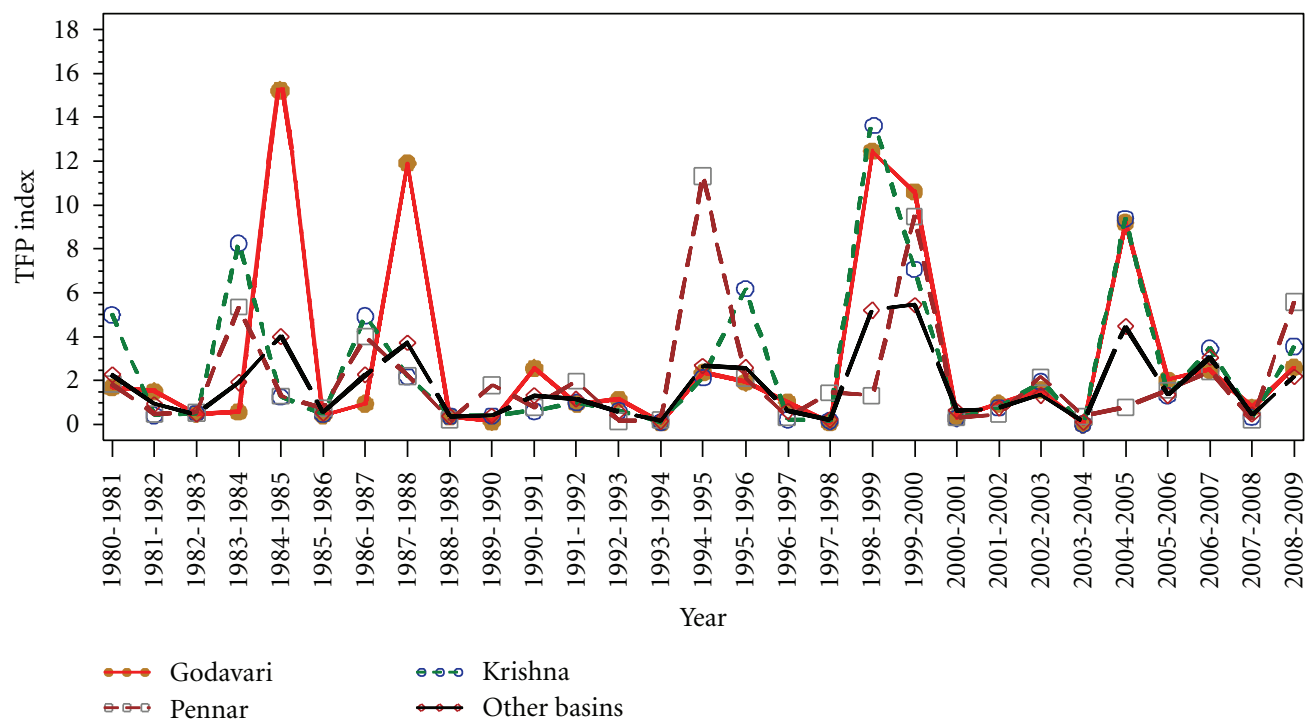

FIGURE 6: Trend in total factor productivity indices in the river basins during 1979-80 to 2008-09.

TABLE 6: River basins whose technical efficiency changes are less than 1 .

\begin{tabular}{lc}
\hline Basin & Tech.eff.Change \\
\hline Bahuda & 0.959 \\
Mahendratanya & 0.958 \\
Poondi minor drain & 0.961 \\
Naupada minor drain & 0.967 \\
Vamsadhara & 0.969 \\
Nagavali & 0.963 \\
Pedda Gedda & 0.962 \\
Kandivalasa Gedda & 0.96 \\
Champavathi & 0.956 \\
Gosthani & 0.959 \\
Manneru & 0.998 \\
Kandeleru (Chippaleru) & 0.998 \\
Pennar & 0.999 \\
Palar & 0.999 \\
\hline
\end{tabular}

TABLE 7: Ranks of the river basins in terms of cumulative TFP indices.

\begin{tabular}{lcccc}
\hline & Godavari & Krishna & Pennar & Other Basins \\
\hline Rank 1 & 14 & 1 & 12 & 1 \\
Rank 2 & 7 & 2 & 3 & 16 \\
Rank 3 & 4 & 3 & 10 & 11 \\
Rank 4 & 3 & 22 & 3 & 0 \\
\hline
\end{tabular}

1979-80 to $1988-89$ and it had picked up in the last decade (1999-2000). Krishna basin has the highest growth rate (6.57\%) followed by Godavari (5.875\%) during this period. These two basins show the highest annual growth rates in gross-irrigated area. Growth rate of labour stabilized around $1.5 \%$ in all the basins. Fertilizer consumption showed annual growth rate of around 5\% in all the basins during the three

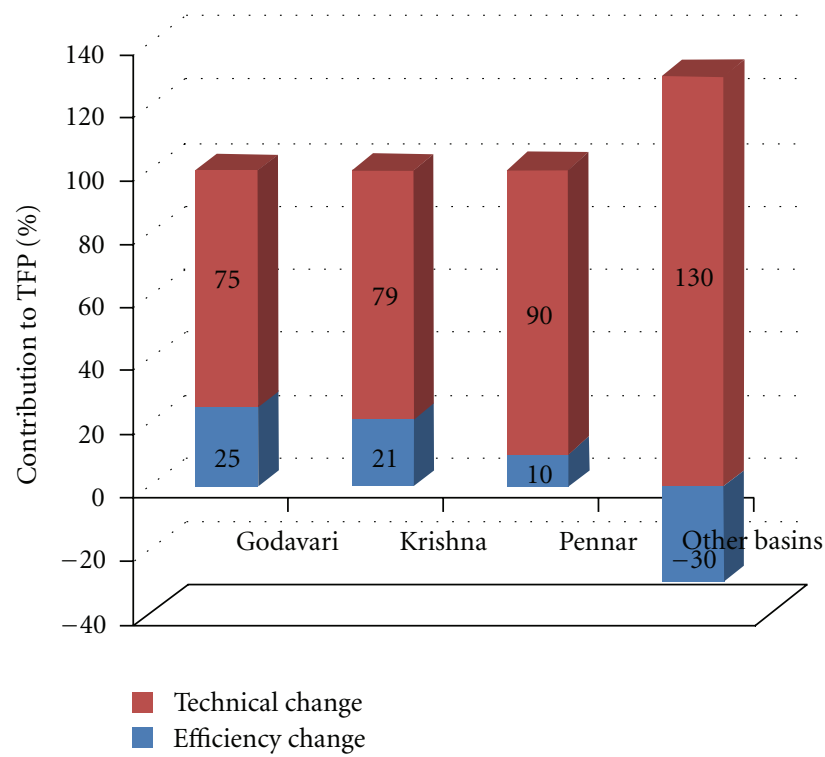

Figure 7: Contribution of technical change and efficiency change to TFP.

decades. Similar trend existed in terms of the other two inputs, namely, tractors and pump sets except at Pennar basin where there is a decline in the growth rate of these inputs during the last decade.

All the river basins have TFP change greater than 1 indicating progress in agricultural productivity in all the basins. Godavari, Krishna, and Pennar basins have TFP changes $1.211,1.152$, and 1.169 , respectively, contributed by both technical efficiency change and technical change. Out of the 40 river basins, 14 river basins have technical efficiency change less than 1 indicating decline in TFP growth and the figures for Godavari, Krishna, and Pennar basins are, respectively, 1.029, 1.027 and 0.999 . In the case of technical 
TABLE 8: Total factor productivity growth in river basins.

\begin{tabular}{|c|c|c|c|c|c|}
\hline & Period & Godavari & Krishna & Pennar & Other Basins \\
\hline \multirow{4}{*}{ TFP growth } & $1979-80$ to $88-89$ & -9.850 & -10.306 & 0.148 & -7.216 \\
\hline & $1989-90$ to $98-99$ & 17.009 & 25.149 & 19.244 & 14.439 \\
\hline & $1999-00$ to $2008-09$ & 22.834 & 22.281 & 19.567 & 13.129 \\
\hline & $1979-80$ to $2008-09$ & 0.588 & -0.021 & 0.009 & 0.008 \\
\hline \multirow{4}{*}{ Technical change } & $1979-80$ to $88-89$ & -7.021 & -6.801 & -2.502 & -6.214 \\
\hline & $1989-90$ to $98-99$ & 17.949 & 18.867 & 17.329 & 16.520 \\
\hline & $1999-00$ to $2008-09$ & 17.111 & 17.669 & 17.582 & 17.112 \\
\hline & $1979-80$ to $2008-09$ & 0.427 & 0.270 & -0.224 & 0.226 \\
\hline \multirow{4}{*}{ Efficiency change } & $1979-80$ to $88-89$ & -3.038 & -3.760 & 2.724 & -1.068 \\
\hline & $1989-90$ to $98-99$ & -0.782 & 5.284 & 1.632 & -1.786 \\
\hline & $1999-00$ to $2008-09$ & 4.934 & 3.904 & 1.682 & -3.398 \\
\hline & $1979-80$ to $2008-09$ & 0.153 & -0.289 & 0.233 & -0.218 \\
\hline
\end{tabular}

TABLE 9: Contribution of TFP, its components and inputs to agricultural growth in river basins (in percentage).

\begin{tabular}{|c|c|c|c|c|c|}
\hline & & $1979-80$ to $88-89$ & $1989-90$ to $98-99$ & 1999-00 to 2008-09 & $1979-80$ to $2008-09$ \\
\hline \multirow{7}{*}{ Godavari } & Output growth rate & -3.7 & -1.0 & 5.9 & 0.3 \\
\hline & TFP growth rate & -9.8 & 17.0 & 22.8 & 0.6 \\
\hline & Tech change growth rate & -7.0 & 17.9 & 17.1 & 0.4 \\
\hline & (a) Contribution of TFP & 269.5 & -1711.1 & 388.7 & 235.2 \\
\hline & (i) Contribution of technical change & 192.1 & -1805.6 & 291.2 & 170.9 \\
\hline & (ii) Contribution of efficiency change & 77.4 & 94.5 & 97.4 & 64.3 \\
\hline & (b) Contribution of Inputs & -169.5 & 1811.1 & -288.7 & -135.2 \\
\hline \multirow{7}{*}{ Krishna } & Output growth rate & -0.6 & -1.7 & 6.6 & 0.7 \\
\hline & TFP growth rate & -10.3 & 25.1 & 22.3 & 0.0 \\
\hline & Tech change growth rate & -6.8 & 18.9 & 17.7 & 0.3 \\
\hline & (a) Contribution of TFP & 1597.1 & -1508.7 & 339.1 & -3.0 \\
\hline & (i) Contribution of technical change & 1053.9 & -1131.8 & 268.9 & 37.8 \\
\hline & (ii) Contribution of efficiency change & 543.2 & -376.8 & 70.2 & -40.8 \\
\hline & (b) Contribution of Inputs & -1497.1 & 1608.7 & -239.1 & 103.0 \\
\hline \multirow{7}{*}{ Pennar } & Output growth rate & -1.4 & -2.1 & 3.6 & -0.5 \\
\hline & TFP growth rate & 0.1 & 19.2 & 19.6 & 0.0 \\
\hline & Tech change growth rate & -2.5 & 17.3 & 17.6 & -0.2 \\
\hline & (a) Contribution of TFP & -10.5 & -897.5 & 550.1 & -1.6 \\
\hline & (i) Contribution of technical change & 176.3 & -808.2 & 494.3 & 42.0 \\
\hline & (ii) Contribution of efficiency change & -186.7 & -89.3 & 55.8 & -43.6 \\
\hline & (b) Contribution of inputs & 110.5 & 997.5 & -450.1 & 101.6 \\
\hline \multirow{7}{*}{ Other basins } & Output growth rate & -2.3 & -1.9 & 4.3 & -0.6 \\
\hline & TFP growth rate & -7.2 & 14.4 & 13.1 & 0.0 \\
\hline & Tech change growth rate & -6.2 & 16.5 & 17.1 & 0.2 \\
\hline & (a) Contribution of TFP & 311.0 & -756.5 & 306.4 & -1.4 \\
\hline & (i) Contribution of technical change & 267.9 & -865.6 & 399.3 & -40.7 \\
\hline & (ii) Contribution of efficiency change & 43.2 & 109.1 & -92.9 & 39.3 \\
\hline & (b) Contribution of inputs & -211.0 & 856.5 & -206.4 & 101.4 \\
\hline
\end{tabular}

change, all the 40 river basins have changes greater than 1 implying that there is shift in production frontier over years. This shows the effectiveness of use of modern technology in agriculture in Andhra Pradesh.

Regarding the agricultural output growth, the contribution is mainly from total factor productivity and the contribution from inputs is negative during the first decade (1979-80 to 88-89) in all basins (except Pennar) and during the third decade (1999-00 to 2008-09) whereas during the second decade (1989-90 to 98-99) the contribution is from inputs only. Overall, in Godavari basin agricultural growth is due to TFP growth whereas contribution from inputs is 
negative. In the remaining basins, inputs have about 101\% to $103 \%$ of contribution to agricultural growth and TFP contribution is negative but negligible. In general, within the TFP, technical change contributed more than technical efficiency change.

Looking at the future options for increasing the agricultural output in the river basins, it is important to focus on improving the TFP growth compared to increasing the quantities of physical inputs. As revealed in the study, although all the basins have shifted towards frontier, about $35 \%$ of them still need to be improved in efficiency of the input use. This can be achieved through intensified agricultural extension programs in using the modern agriculture and irrigation technologies, specifically converging of the different agricultural development programs and strengthening the capacity building programs at the village level which will include crop management programs like SRI. Water management programs like alternate wetting and drying for paddy and micro irrigation for horticultural crops are important.

\section{Acknowledgment}

This paper is based on data collected and analysed as part of Climarice 2 project (2010-2013) (http://www.climarice.org) under IWMI-Bioforsk project funded by The Norwegian Embassy, New Delhi.

\section{References}

[1] T. Coelli, D. S. P. Rao, and G. E. Battesse, An Introduction to Efficiency and Productivity Analysis, Kluwer Academic, Norwell, Mass, USA, 1998.

[2] R. Majumdar and M. H. B. Subrahmanya, "Total factor productivity growth and output growth in Indian electronics industry in the liberalization era: an empirical examination," in Proceedings of the Singapore Economic Review Conference, Singapore, August 2007.

[3] R. Färe, S. Grosskopf, M. Norris, and Z. Zhang, "Productivity growth, technical progress, and efficiency change in industrialized countries," American Economic Review, vol. 84, no. 1, pp. 66-83, 1994.

[4] T. J. Coelli and D. S. Rao, "Total factor productivity growth in agriculture: a malmquist index analysis of 93 countries, 19802000," CEPA Working Papers No. 2/2003, p. 13, School of Economics, University of New England, Armidale, Australia, 2003.

[5] T. J. Coelli and D. S. P. Rao, “Total factor productivity growth in agriculture: a Malmquist index analysis of 93 countries, 1980-2000," Agricultural Economics, vol. 32, supplement 1, pp. 115-134, 2005.

[6] C. Yuk-shing, Productivity Growth, Technical Progress and Efficiency Change in Chinese Agriculture, Department of Economics, Hong Kong Baptist University, Kowloon, Hong Kong, 1998.

[7] S. Rungsuriyawiboon and A. Lissitsa, "Total factor productivity growth in European agriculture," http://www.nesdb.go.th/ econSocial/macro/TNCE/Download/1/supawat.pdf.

[8] C. Umetsu, T. Lekprichakul, and U. Chakravorty, "Efficiency and technical change in the Philippine rice sector: a Malmquist total factor productivity analysis," American Journal of Agricultural Economics, vol. 85, no. 4, pp. 943-963, 2003.

[9] V. H. Linh, "Vietnam's agricultural productivity: a Malmquist index approach," 2009, http://www.vdf.org.vn/workingpapers /vdfwp0903.pdf.

[10] K. Palanisami, C. R. Ranganathan, A. Vidhyavathi, M. Rajkumar, and N. Ajjan, "Performance of agriculture in river basins of Tamil Nadu in the last three decades - a total factor productivity approach," 2011, http://planningcommission. nic.in/reports/sereport/ser/ser_river1905.pdf.

[11] M. J. Farrell, "The measurement of productive efficiency," Journal of the Royal Statistical Society, vol. 120, pp. 253-290, 1957.

[12] T. J. Coelli, A Guide to DEAP Version 2.1: A Data Envelopment Analysis (Computer) Program, Department of Econometrics, University of New England, Armidale, Australia, 2008.

[13] Government of Andhra Pradesh, "Season and Crop Report Andhra Pradesh, 2008-2009,” 2009. 


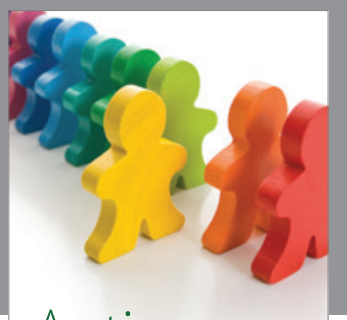

Autism

Research and Treatment
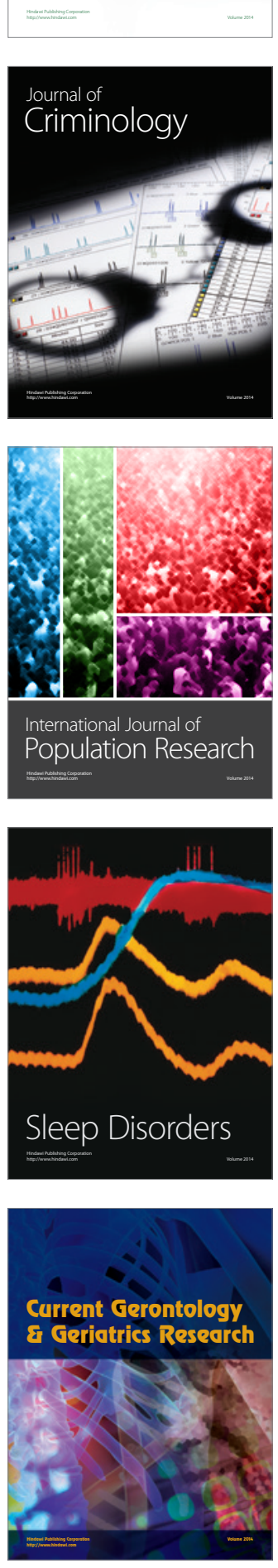
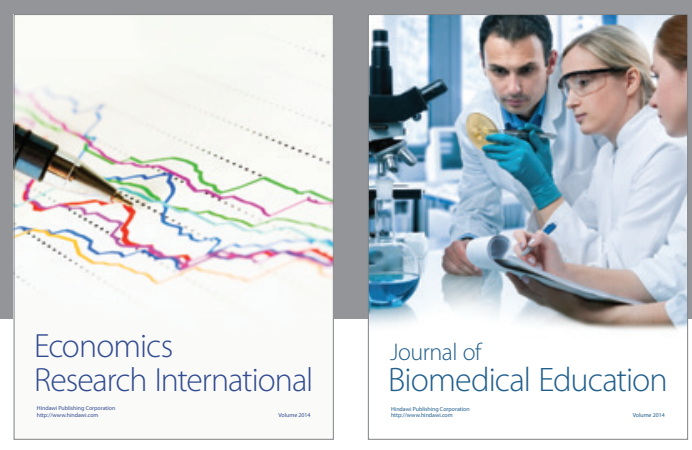

Journal of

Biomedical Education

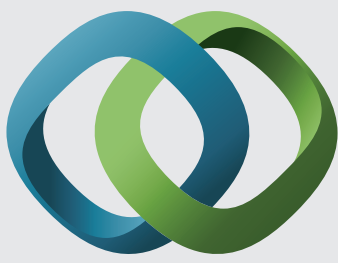

\section{Hindawi}

Submit your manuscripts at

http://www.hindawi.com
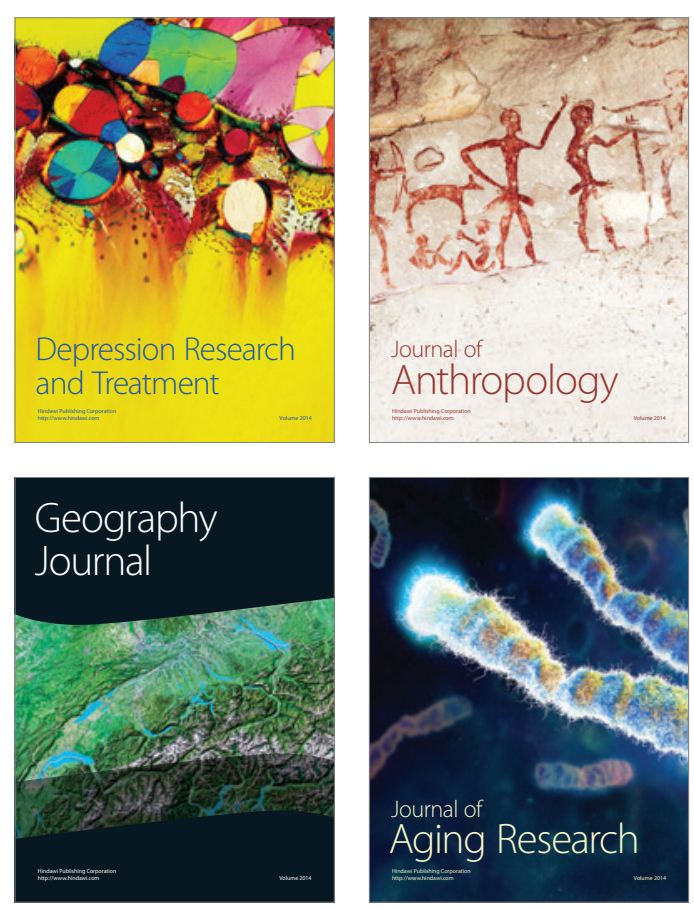

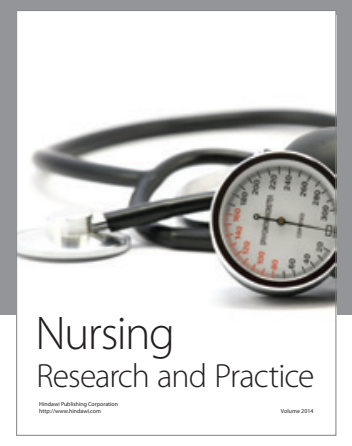

Nursing

Research and Practice

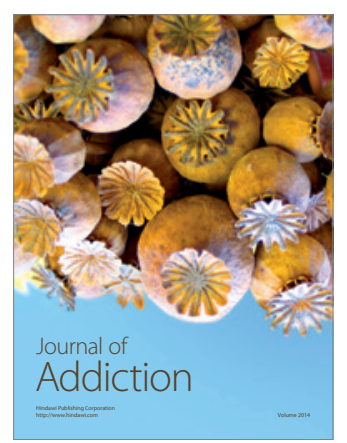

Child Development

Research

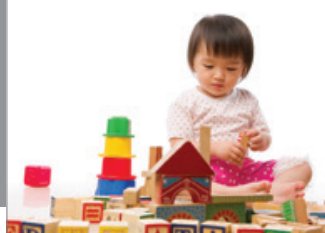

迥
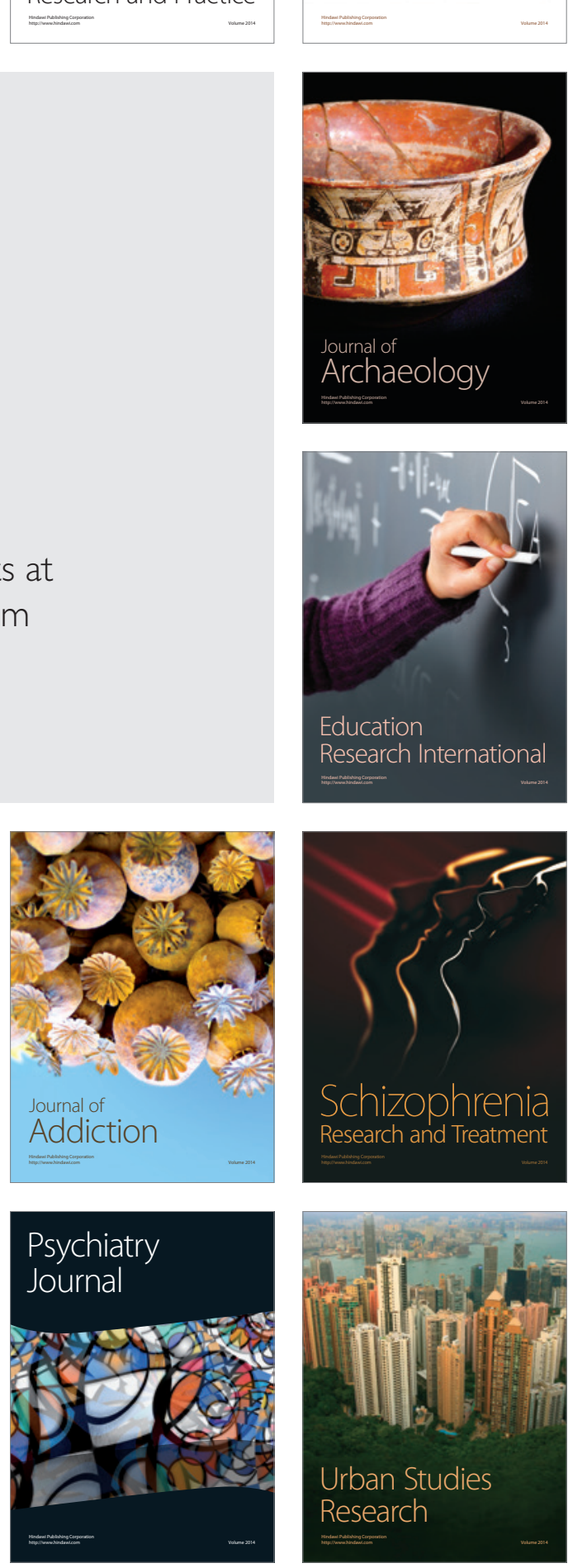